Houpert Loïc (Orcid ID: 0000-0001-8750-5631)

Cunningham Stuart (Orcid ID: 0000-0001-9439-5442)

Fraser Neil (Orcid ID: 0000-0002-2171-9060)

Johnson Clare (Orcid ID: 0000-0002-8213-2554)

Holliday N. Penny (Orcid ID: 0000-0002-9733-8002)

Jones Sam (Orcid ID: 0000-0001-7371-9014)

Moat Bengamin (Orcid ID: 0000-0001-8676-7779)

Rayner D. (Orcid ID: 0000-0002-2283-4140)

\title{
Observed variability of the North Atlantic Current in the Rockall Trough from four years of mooring measurements
}

\author{
L. Houpert ${ }^{1}$, S. Cunningham ${ }^{2}$, N. Fraser ${ }^{2}$, C. Johnson ${ }^{2}$, N. P. Holliday ${ }^{1}$, S. \\ Jones $^{2}$, B. Moat ${ }^{1}$, D. Rayner ${ }^{1}$
}

${ }^{1}$ National Oceanography Centre, Southampton, UK

${ }^{2}$ Scottish Association for Marine Science, Oban, UK

Corresponding author: Loïc Houpert (loic.houpert@noc.ac.uk)

\section{Key Points}

- Around half of the northward transport of the warm North Atlantic Current (NAC), flows through the Rockall Trough

- The first continuous observations of Rockall Trough transport show that 6.6 Sv is carried northward in the NAC.

- High northward transport is characterised by a strong NAC jet in the Rockall Trough; weak transport by mesoscale eddy activity

This article has been accepted for publication and undergone full peer review but has not been through the copyediting, typesetting, pagination and proofreading process which may lead to differences between this version and the Version of Record. Please cite this article as doi: 10.1029/2020JC016403 


\section{Abstract}

The Rockall Trough is one of the main conduits for warm Atlantic Water to the Nordic Seas. Ocean heat anomalies, originating from the eastern subpolar gyre, are known to influence Arctic sea ice extent, marine ecosystems, and continental climate. Knowledge of the transport through this basin has previously been limited to estimates from hydrographic sections which cannot characterise the intra-annual and multi-annual variability. As part of the Overturning in the Subpolar North Atlantic Programme (OSNAP), a mooring array was deployed in the Rockall Trough in order to obtain the first continuous measurements of transport. Here, we define the methodology and the errors associated with estimating these transports. Results show a 4-year mean northward transport of $6.6 \mathrm{~Sv}\left(1 \mathrm{~Sv}=10^{6} \mathrm{~m}^{3} / \mathrm{s}\right)$ by the North Atlantic Current (NAC) in the east and interior of the Rockall Trough (2014-2018). A mean transport of -2.0 Sv (southward) is observed in the west of the basin, which could be part of a recirculation around the Rockall Plateau. The 90-day low-pass filtered transport shows large sub-annual and inter-annual variability (-1.6 Sv to 9.1 Sv), mostly resulting from changes in the mid-basin geostrophic transport. Satellite altimetry reveals the periods of low and high transport are associated with significant changes in the Rockall Trough circulation. There is a detectable seasonal signal, with the greatest transport in spring and autumn.

\section{Plain Language Summary}

There is mounting evidence that the North Atlantic Current (eastward extension of the Gulf Stream) heavily influences the European and Arctic climate. To adequately measure this current and understand its dynamics, an array of underwater instruments was deployed in the Rockall Trough, a remote region of the eastern North Atlantic. Over a four-year period, these instruments continuously collected measurements of temperature, salinity, pressure and velocity data. Analysis of these data provides a new and more accurate description of the North Atlantic Current in this region. This study reveals a surprisingly large variability in the eastern North Atlantic circulation. The combined analysis of satellite data indicates that this variability is due to changes of the North Atlantic Current system. 


\section{Introduction}

In 2014, the Overturning in the Subpolar North Atlantic Programme (OSNAP) established an array of more than fifty moorings across the subpolar North Atlantic, with the objective of continuously measuring the strength, structure and variability of the circulation. The array is able to diagnose both the horizontal and overturning circulations and their associated fluxes of heat and fresh-water. The programme combines measurements of the temperature, salinity and directly measured currents, with salinity and temperature fields derived from purposefully deployed ocean gliders, Argo floats and hydrographic cruises, with satellite altimetry and mass balance constraints.

Results from the first 21 months of the array (August 2014 to April 2016) were reported in Lozier et al. (2019) and provide remarkable evidence that the majority of the overturning occurs north of the OSNAP east section between East Greenland and Scotland. The Atlantic Meridional Overturning Circulation (AMOC) strength at

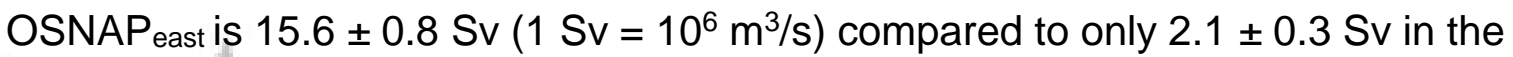
Labrador Sea north of OSNAP west. The zonally-integrated meridional volume fluxes along OSNAP east show that there is $12.2 \mathrm{~Sv}$ of upper-limb transport associated with the North Atlantic Current (NAC, defined as water with potential density $\left.\sigma_{0}<27.66 \mathrm{~kg} / \mathrm{m}^{3}\right)$. Of this $12.2 \mathrm{~Sv}$, OSNAP data show that $43 \%(5.2 \mathrm{~Sv})$ of the flow is east of $13.0^{\circ} \mathrm{W}$, through the Rockall Trough. From this 12.2 Sv of NAC transport, 58 to $69 \%$ is carried poleward over the Greenland-Scotland Ridge (7.1-8.4 Sv) via the Iceland-Faroe Ridge, the Faroe-Shetland slope current and the European Shelf (Berx et al., 2013; Hansen et al., 2015; Østerhus et al., 2019; Rossby \& Flagg, 2012; Figure 1). 

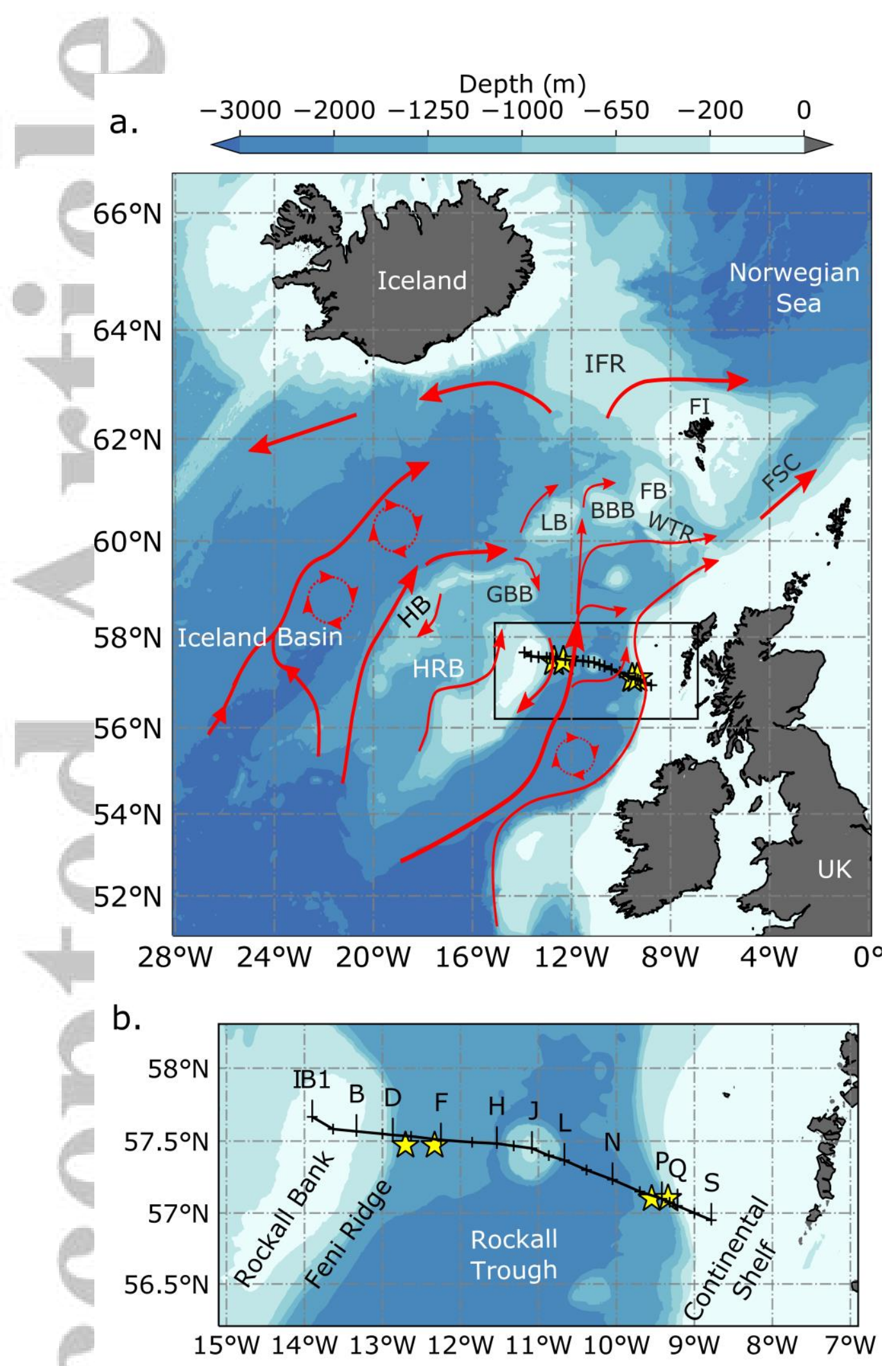

Figure 1: Bathymetry and schematic of the North Atlantic upper-ocean circulation $\left(\sigma_{0}<27.55 \mathrm{~kg} / \mathrm{m}^{3}\right)$ over the $2014-2018$ period (a) and bathymetry of the Rockall Trough (b). Circulation schematic is based on absolute geostrophic current from altimetry averaged over 2014-2018 (Figure S1), Houpert et al. (2018) for the 
Hatton-Rockall Basin circulation, and the new results presented in this study.

Altimetry-derived currents are representative of the large-scale flow associated with the NAC branches, therefore the circulation schematic drawn in the Rockall Trough is mostly representing a period of high transport as defined in the manuscript by the high transport composite state. The black box indicates the region shown on (b). UK-OSNAP moorings are indicated by yellow stars and the Extend Ellet Line hydrographic stations used in this study are indicated by black crosses and labelled on (b). Acronyms: IFR = Iceland-Faroe Ridge, FI = Faroe Islands, FB = Faroe Bank, FSC $=$ Faroe-Shetland Channel, LB = Lousy Bank, BBB = Bill Bailey Bank, WTR = Wyville Thomson Ridge, HB = Hatton Bank, GBB = George Bligh Bank, HRB = Hatton-Rockall Basin

The OSNAP Rockall Trough mooring array (Figure 2a) is designed to quantify the transport of northward-flowing warm and saline water, and the magnitude of the southward-flowing cold overflow water across the Wyville Thomson Ridge (Johnson et al., 2017). The location and the multi-decadal context are determined by the long-established Ellett Line section, 62 occupations in the Rockall Trough since 1975. In 1996, the hydrographic section was extended to Iceland and the Ellett Line project became the Extended Ellett Line project (EEL). From 2018, the Rockall Trough mooring array is funded under the Ellett Array project, under the Natural Environment Research Council's National Capability programme CLASS (Climate Linked Atlantic Sector Science, https://projects.noc.ac.uk/class-project/). The mooring array is complemented by UK glider measurements across the Hatton-Rockall Basin (Houpert et al., 2018).

The Rockall Trough NAC branch is warmer and more saline than Iceland Basin NAC branches, and contributes to the freshwater budgets and heat supply to the Nordic Seas. Observations and models broadly agree on the mean structure and pathways but the NAC's variability and branching structure is poorly understood (Hansen et al., 2008). The variability of the strength and properties of the NAC are thought to be driven by the horizontal expansion and contraction of the subpolar gyre due to multi-annual thermohaline forcing (Häkkinen \& Rhines, 2004; Hjálmar Hátún et al., 2005). When the subpolar front retreats to the west, the temperature and salinity of upper waters in the Rockall Trough increase, with these changes propagating into the Nordic Seas (Holliday et al., 2008). Estimates of net northward transport through the Rockall Trough show that it is contained in two main currents: a shelf edge 
current and a current in the interior of the basin. The shelf edge current, found at depths $<1000 \mathrm{~m}$, is driven by the large-scale density distribution of the north-eastern Atlantic (Huthnance, 1984; Marsh et al., 2017). Variability of the shelf edge current on inter-annual timescales is likely due to changes to the large-scale density distribution, particularly at the entrance to the Rockall Trough (Holliday, 2003). On shorter timescales (seasonal and sub-seasonal), variations in wind forcing are thought to dominate (Souza et al., 2001). A larger proportion of warm NAC water flows northward through the basin interior. Estimates of transport from the Rockall Trough part of the EEL sections are $3.7 \pm 2.4 \mathrm{~Sv}$ (mean \pm standard deviation) between 1975 and 1998, and 3.0 \pm 3.7 Sv between 1997 and 2014 (Holliday et al., 2000, 2015). Gary et al. (2018) showed it is difficult to detect a seasonal cycle in the volume transport from hydrographic observations because of high mesoscale variability. Thus, little is known about the intra- and inter-annual variability associated with transport through the Rockall Trough.

The Rockall Trough is separated from the Faroe-Shetland Channel by the Wyville Thomson Ridge, limiting northward transport to depths $<650 \mathrm{~m}$ (Figure 1). A net southward transport of - $0.3 \mathrm{~Sv}$ of Wyville Thomson Overflow Water has been detected at the location of the EEL and mooring array (Johnson et al., 2010, 2017; Sherwin et al., 2008).

In this paper we analyse four years of data (July 2014-July 2018) from the OSNAP Rockall Trough mooring array, quantifying, for the first-time, the variability at sub-seasonal, seasonal and interannual timescales. Firstly, we present the data which is collected from instruments on the Rockall Trough moorings (Section 2), before describing the methodology used to calculate the volume transports (Section 3). Next, we make comprehensive estimates of the uncertainties that arise from our sampling scheme, instrumental factors, processing methodologies and missing data (Section 4). In Section 5 we describe and discuss the results in the context of historical understanding of the circulation. The key issues are discussed in Section 6.

are shown as black contour lines. The design of the UK-OSNAP mooring array deployed since 2014 in the Rockall Trough is superimposed. The different sub-regions used in the calculation of the volume flux are indicated on top. Acronym: CS, Continental Shelf. (b) and (c) are the pressure time-series from the Rockall Trough WB and EB mooring instruments used in this study. Sea-Bird SBE37 MicroCAT CTDs are indicated in red, Nortek Aquadopp current meters in blue and 
reconstructed near-surface instrument at EB1 from March to May 2017 in black (see Data section for more details).

\section{Data}

\subsection{The Rockall Trough mooring array}

The array (Figure 2a) consists of three sub-surface taught wire moorings (WB1, WB2 and EB1), and one Acoustic Doppler Current Profiler (ADCP) within a trawl resistant frame (ADCP1). All moorings were first deployed in July 2014, except ADCP1 which was deployed in October 2014. The WB1, WB2 and EB1 moorings consist of Sea-Bird SBE37 MicroCAT CTDs (measuring conductivity, temperature and pressure) and Nortek Aquadopp current meters (measuring pressure and velocity). The pressure time-series of the instruments are indicated in Figure $2 \mathrm{~b}$. All moorings were recovered and redeployed in June 2015, July 2016, May 2017, and July 2018.

The two boundary currents in the west and east of the Rockall Trough are measured directly using current meters. The sub-surface WB1 mooring $\left(57.5^{\circ} \mathrm{N}\right.$, $12.7^{\circ} \mathrm{W}$, water depth of $1600 \mathrm{~m}$ ) was deployed to capture the narrow southward boundary current seen in repeated Lowered Acoustic Doppler Current Profiler (LADCP) sections (Figure 2a). This jet extends from $13.0^{\circ} \mathrm{W}$ (EEL station $\mathrm{C}$ ) to $12.5^{\circ} \mathrm{W}$ (mid-way between EEL stations $\mathrm{E}$ and $\mathrm{F}$, Figure 2a). The EB1 sub-surface mooring $\left(57.1^{\circ} \mathrm{N}, 9.6^{\circ} \mathrm{W}\right.$, water depth of $\left.1800 \mathrm{~m}\right)$, and the ADCP mounted on trawl resistant frame $\left(57.1^{\circ} \mathrm{N}, 9.3^{\circ} \mathrm{W}\right.$, water depth of $\left.750 \mathrm{~m}\right)$, were deployed in the eastern Rockall Trough (Figure 1) to capture the shelf edge current extending from $9.6^{\circ} \mathrm{W}$ to $9.2^{\circ} \mathrm{W}$ (water depth of $250 \mathrm{~m}$ ) as seen on Figure 2a. The CTDs on WB1/WB2 and EB1 are used to compute dynamic height profiles at the western and eastern boundary of the Rockall Trough in order to compute the mid-basin geostrophic transport.

Data were processed using the methods developed for the RAPID array (McCarthy et al., 2015; Rayner et al., 2011). Sea-Bird CTDs were calibrated pre and post deployment by lowering on a CTD cast and instrument drifts were corrected. Velocity data were corrected for magnetic deviations and speed of sound. Velocity and CTD data were interpolated to a common timebase and filtered using a 40 hour 
Butterworth filter to remove signals from tides and inertial oscillations. At each timestep, we linearly interpolated the relatively sparse moored instrument data onto a high resolution vertical grid (20 dbar grid). The errors due to this linear interpolation onto a high resolution vertical grid is discussed in Supplementary Text S1. The surface gaps were filled by linearly extrapolating the velocity profiles and the dynamic height profiles to the surface.

Data return from the CTDs and current meters was very high as can be seen in Figure $2 b$. Small losses have occurred due to battery failures and fishing damage to the top of mooring EB1 between March and May 2017. In March 2017, the top $400 \mathrm{~m}$ of the EB1 mooring broke due to fishing activities. Although the CTD and current meter deployed at $100 \mathrm{~m}$ were later recovered from a Scottish Island, the CTD deployed at $250 \mathrm{~m}$ was lost. Data from the CTD at $100 \mathrm{~m}$ was used until the point at which the mooring broke. After this (March 2017-May 2017), we reconstructed the temperature and salinity using linear regressions with the timeseries from $100 \mathrm{~m}$ at WB1 (correlation coefficients of 0.93 for temperature and 0.85 for salinity over 2014-2016). The pressure time-series associated with this reconstructed temperature and salinity at $100 \mathrm{~m}$ depth on EB1 is shown in black on Figure $2 \mathrm{c}$ (more details in Text S1). Unfortunately, data return from ADCP1 is limited to one 8-month deployment in 2014. All other deployments failed despite the use of trawl-resistant frames. Several of the frames, minus the ADCPs, have been recovered with evidence of trawling damage. Additionally, one unrecoverable unit was filmed in situ on the seabed by a deep diving autonomous submersible in July 2019. The lander was seen to be ploughed deeply into the mud and extensively damaged, with the ADCP torn from the lander frame gimbal mount and lying on the seabed. This lander was washed ashore in the Outer Hebrides in March 2020. From 2020, gliders are deployed in the shelf edge current to provide continuous observations between the $200 \mathrm{~m}$ contour and the $2000 \mathrm{~m}$ contour westward of the EB1 mooring.

\subsection{Ancillary Data}

LADCPs measure full-depth currents on CTD casts and have been deployed on EEL hydrographic sections since 1996. Between 1996 and 2004 the instruments 
used were $150 \mathrm{kHz}$ broadband ADCPs and data were processed using software developed by Eric Firing at the University of Hawaii. From 2005 onwards, $300 \mathrm{kHz}$ broadband ADCPs were used and their data were processed using the IX Lamont- Doherty Earth Observatory software (Thurnherr, 2014). LADCP absolute velocities from both methods have an uncertainty of 0.02-0.03 m/s (Holliday et al., 2009; Thurnherr, 2014). Data were de-tided using barotropic tides at the time of each cast, obtained from the Oregon State University Tidal Inversion Software (Egbert \& Erofeeva, 2002; https://www.tpxo.net/).

We use gridded and along-track delayed mode data of daily global sea-level anomalies, absolute sea-surface dynamic topography, surface absolute geostrophic velocities and velocity anomalies at a spatial resolution of $0.25^{\circ}$. Data were obtained from the SSALTO/DUACS (Segment Sol multi-missions dALTimetrie, d'orbitographie et de localisation précise / Data Unification and Altimeter Combination System) system (Pujol et al., 2016), distributed through the Copernicus Marine and Environment Monitoring Service (http://marine.copernicus.eu/documents/QUID/CMEMS-SL-QUID-008-032-051.pdf). The data were analysed from 1 July 2014 to 1 July 2018. We used the gridded surface geostrophic velocity anomalies derived from the Sea Level Anomaly gradients to calculate the Eddy Kinetic Energy (EKE), as one half of the sum of the squared eddy velocity components.

Surface wind stress data were extracted from the European Centre for Medium-Range Weather Forecasts reanalysis, ERA5 (https://www.ecmwf.int/en/forecasts/datasets/reanalysis-datasets/era5). ERA5 has a horizontal resolution of $30 \mathrm{~km}$ and provides hourly estimates of atmospheric, land and oceanic climate variables. In this study, we use 6h-output covering July 2014 to July 2018.

Daily time-series of horizontal velocity from the GLORYS12V1 product are extracted at the location of ADCP1. GLORYS12V1 is the Copernicus Marine and Environment Monitoring Service global ocean eddy-resolving reanalysis covering the altimetry era from $1993\left(1 / 12^{\circ}\right.$ horizontal resolution and 50 vertical levels, http://resources.marine.copernicus.eu/documents/PUM/CMEMS-GLO-PUM-001-030 .pdf). The model component is the NEMO platform driven at the surface by European Centre for Medium-Range Weather Forecasts ERA-Interim reanalysis. 
Climatological upper-ocean temperature and salinity were extracted from the Monthly Isopycnal / Mixed-layer Ocean Climatology, MIMOC (Schmidtko et al., 2013). MIMOC has a $0.5^{\circ}$ lateral resolution and 81 standard pressure levels between 0-1950 dbar.

\section{Transport Calculation}

The total transport (Ттот) through the Rockall Trough is calculated as the sum of the transport in the western wedge $\left(T_{W W}\right)$, the mid-basin $\left(T_{M B}\right)$, and the eastern wedge ( $\left.T_{E W}\right)$ (Eq.1, Figure2a).

$$
\begin{aligned}
T_{\text {TOT }} & =\iint_{R T \text { section }} v(x, z) d x d z \\
& =\iint_{W W} v d x d z+\iint_{M B} v d x d z+\iint_{E W} v d x d z \quad \text { (Eq. 1) } \\
& =\mathrm{T}_{W W}+\mathrm{T}_{\mathrm{MB}}+\mathrm{T}_{\mathrm{EW}}
\end{aligned}
$$

Mid-basin transport is estimated from dynamic height moorings WB1 and WB2 in the west, and EB1 in the east. Transport in the western wedge is calculated from current meter data from mooring WB1. Eastern wedge transport is calculated from current meter data from the EB1 and ADCP1 moorings and ocean reanalysis. In addition, the meridional wind-driven Ekman transport is computed as a function of the zonal component of the wind-stress following Gary et al. (2018).

\subsection{Mid-basin transport}

We compute the mid-basin geostrophic shear from the surface to the depth $z_{\text {ref }}=1760 \mathrm{~m}$. In the east, the bathymetry enables mooring EB1 to be deployed at $z_{\text {ref }}$. However, in the west, a sedimentary body produced by the accumulation of sediment under the control of bottom currents, the Feni Ridge (Figure 1b, [Howe et al., 2001]), interrupts the steep bathymetry at $1600 \mathrm{~m}$, with mooring WB1 placed on the top of this feature. Thus, to extend the depth of the geostrophic shear calculations, we also rely on mooring WB2, which is located further east at $1800 \mathrm{~m}$ 
depth. We merge the data from WB1 and WB2 following the RAPID methodology to create temperature and salinity profiles that extend to $z_{\text {ref }}$ (McCarthy et al., 2015, sub-section "Design of the array"). We set the location of this merged dynamic height mooring to half way between WB1 and WB2.

The mid-basin calculation requires a known velocity at one depth level. We chose not to reference our mid basin geostrophic velocities to satellite altimetry because of the significant uncertainty associated with the gridded Absolute Dynamic Topography (ADT). By defining the uncertainty of the gridded ADT as the standard deviation of the difference between the along-track and gridded ADT data, we find a mean slope error of $5.0 \mathrm{~cm}\left(\sqrt{2.7^{2}+3.9^{2}}\right)$, equivalent to a transport error of $6.8 \mathrm{~Sv}$ across our section (Appendix A). Therefore, we use a single level of no motion. Previous work set a constant level of no motion across the Rockall Trough (Ellett \& Martin, 1973; Holliday et al., 2000, 2015). However, the mooring array shows barotropic flow at both the eastern and western boundaries, so we use the deepest depth level of the dynamic height moorings $\left(z_{r e f}\right)$ as the level of no motion. This gives a basin-wide transport below $1250 \mathrm{~m}$ of approximately $-0.3 \mathrm{~Sv}$. The southern entrance of the Rockall Trough is the only pathway deeper than $1250 \mathrm{~m}$. Below this depth, the northward-flowing waters are blocked by the topography (Holliday et al., 2000) and only a small net southward transport of dense Wyville Thomson Overflow Water has been reported (-0.3 Sv, Johnson et al., 2017). By integrating the dynamic

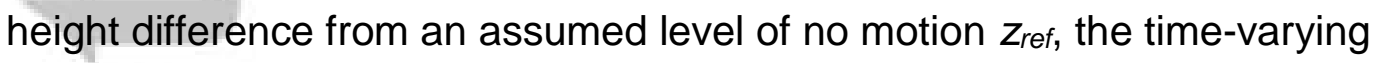
geostrophic velocity between the two dynamic height moorings WB and EB1, VMB can be expressed as:

$v_{M B}(z)=v\left(z_{\text {ref }}=1760\right)-\frac{1}{f} \int_{z=1760}^{z} \frac{\Delta \Phi_{E B 1}(z)-\Delta \Phi_{W B}(z)}{L} d z$

$v_{M B}(z)=v_{r e f}-v_{B C}(z)($ Eq. 2)

where $\Delta \Phi$ is the dynamic height anomaly relative to $z_{\text {ref }}$ at the western and eastern boundaries, calculated as the integral of the specific volume anomaly from $z_{\text {ref }}$ to depth $z$. $L$ is the distance between the western and eastern moorings and $f$ is the Coriolis frequency. Following the level of no motion approximation, the reference velocity at $Z_{\text {ref, }} V_{\text {ref, }}$ is equal to zero. The mid-basin transport $\mathrm{T}_{\mathrm{MB}}$ is obtained by integrating Eq. 2 over the mid-basin area. 


\subsection{Western wedge transport}

Transport in the western wedge is calculated by extrapolating the profile of currents measured at WB1 across the western wedge. This region, extending from $13.0^{\circ} \mathrm{W}$ (EEL station C) to $12.5^{\circ} \mathrm{W}$ (mid-way between WB1 and WB2), is characterised by a spatially uniform mean southward current (Figure 2a). The WB1 velocities were extended eastward to $12.5^{\circ} \mathrm{W}$; whilst west of WB1, velocities were linearly interpolated between those at WB1 to zero, either at the eastern boundary of the wedge $\left(13.0^{\circ} \mathrm{W}\right)$ or the seabed if this was intercepted. On Rockall Bank (between $13.5^{\circ} \mathrm{W}$ and $12.9^{\circ} \mathrm{W}$ ), the mean velocities from 11 LADCP sections show evidence of a northward jet (Figure 2a) in the upper $250 \mathrm{~m}$, also indicated by a $V$-shape in the isopycnals. This small northward flow seems to recirculate around Rockall Bank and therefore is excluded from our calculation. Instead, the upper $250 \mathrm{~m}$ of the western wedge is filled by linearly interpolating velocities from WB1 to zero at $12.9^{\circ} \mathrm{W}$, instead of $13.0^{\circ} \mathrm{W}$.

\subsection{Eastern wedge transport}

It was planned that the transport in the eastern wedge would be calculated using velocities measured at EB1 and ADCP1. However, due to repeated losses of $A D C P 1$, we used the GLORYS12v1 ocean reanalysis to recreate velocity time-series at the location of ADCP1. The time-series of ADCP1 depth-average meridional velocity compare well with GLORYS during the 8-month period of available observations ( $r=0.5, p$-value $=0.07$, Figure S2). As the mean difference between the observations and reanalysis is $7.6 \mathrm{~cm} / \mathrm{s}$ (standard deviation of $8.9 \mathrm{~cm} / \mathrm{s}$ ), the GLORYS velocity time-series was offset by $7.6 \mathrm{~cm} / \mathrm{s}$ in order to have the same mean velocity as the ADCP1 deployment (Figure S2). The eastern wedge above $750 \mathrm{~m}$ is filled by linearly interpolating the velocities from the EB1 mooring $\left(9.6^{\circ} \mathrm{W}\right)$ and GLORYS-ADCP (the time-series of adjusted velocities extracted from GLORYS at the ADCP1 location at $9.3^{\circ} \mathrm{W}$ ). East of ADCP1, the eastern wedge is filled with velocities from GLORYS-ADCP by linearly decreasing them to zero at the edge of the continental shelf $\left(9.2^{\circ} \mathrm{W}\right)$. The transport below $750 \mathrm{~m}$ is calculated by uniformly extrapolating the vertical profile of velocity at EB1 to the eastern wedge area. From 
2020, gliders are deployed in the shelf edge current to provide continuous observations between the $200 \mathrm{~m}$ contour and EB1 mooring.

\section{Accuracy of the estimated transport}

The accuracy of the estimated transports is impacted by two types of error: instrumental and methodological (surface extrapolation of mooring data, vertical gridding, and horizontal interpolation of the flow field in the boundary currents). Our aim is to provide a realistic estimate of errors associated with each of these sources, and their net impact on the total flux. In this section we briefly describe the methods and results, with a more detailed description given in Text S1. Instrumental errors were evaluated by error propagation using the pressure, temperature, salinity and velocity accuracies provided by the instrument manufacturers. We evaluate methodological errors using repeat LADCP and CTD data from EEL hydrographic sections and a seasonal climatology of temperature and salinity. We calculate the transports in the boundaries and mid-basin using the full horizontal and vertical resolution of the LADCP/CTD data (method M1) and using a subsampled version of the same dataset (method M2). Method M2 simulates the discrete measurement levels of the moored instruments and reproduces the method used to calculate the mooring array transport (as described in section 3). The mean bias error and RMS (root mean square) error for each region (western wedge, mid-basin and eastern wedge) are defined as the mean of the differences in transport between methods M2 and $M 1$, and the standard deviation of the transport differences respectively. The mean bias error for the section as a whole is calculated as the sum of the regional bias errors, whilst the total RMS error is defined as the square root of the sum of the squared regional RMS errors.

An overall estimate of the error for the total Rockall Trough transport is given by combining the errors associated with the gridding, calibration and vertical extrapolation of the mid-basin dynamic height moorings, with the errors in the western wedge (horizontal extrapolation and instrument accuracy) and eastern wedge (horizontal extrapolation and use of ocean reanalysis). For an optimal data return, such as in 2015-2016 and 2017-2018, the RMS error is $0.93 \mathrm{~Sv}$ and the mean bias error $0.03 \mathrm{~Sv}$. However, instrument failure or losses impact both types of 
error. For example, in 2014-2015 when the CTD at $1000 \mathrm{~m}$ on EB1 failed, the RMS error was $1.10 \mathrm{~Sv}$ and the mean bias error -0.39 Sv. Similar errors were obtained in 2016-2017 when a CTD deployed at 250 m on EB1 was lost (Table S1).

\section{Results}

\subsection{Circulation and transport variability}

\subsubsection{Mean circulation features}

The mean cross-section velocity from EEL LADCP data (1996-2017) shows i) a southward flow in the western wedge, ii) a northward flow between Rockall Bank and the Anton Dohrn seamount superimposed onto an anticyclonic recirculation around the seamount, and iii) a northward flow at the eastern boundary along the continental shelf associated with the shelf edge current (Figure 2a). The 2014-2018 mean of the observed velocity profiles from moorings WB1, WB2, EB1 and ADCP1 (Figure 3) reflect the same flow distribution across the section.

At WB1, there is a mean top-to-bottom southward flow of $-8.0 \mathrm{~cm} / \mathrm{s}$, with a maximum velocity of $-10 \mathrm{~cm} / \mathrm{s}$ near $1350 \mathrm{~m}$ corresponding to the depth of the core of the Wyville Thomson Overflow Water (Johnson et al., 2017). The standard deviation varies from $14.5 \mathrm{~cm} / \mathrm{s}$ at $100 \mathrm{~m}$ depth to $5.8 \mathrm{~cm} / \mathrm{s}$ at $1420 \mathrm{~m}$ depth. At WB2, the mean \pm one standard deviation is $0.3 \pm 4.0 \mathrm{~cm} / \mathrm{s}$ highlighting the eastern limit of this top-to-bottom mean southward flow found in the western wedge.

In the mid-basin, the mean geostrophic current is northward (vertical average of $1.7 \mathrm{~cm} / \mathrm{s}$ ) and surface intensified: the mean current at $100 \mathrm{~m}$ depth is $3.5 \pm 1.8$ $\mathrm{cm} / \mathrm{s}$.

At EB1, the current varies from $5.5 \pm 10.7 \mathrm{~cm} / \mathrm{s}$ near the surface to $1.2 \pm 2.1$ $\mathrm{cm} / \mathrm{s}$ at $1760 \mathrm{~m}$ depth, with a vertical average of $2.5 \mathrm{~cm} / \mathrm{s}$. Over the continental slope, the 8-month record from ADCP1 (Nov. 2014 - Jun. 2015) indicates a mean northward flow which is relatively homogenous with depth. The vertical average of the mean northward current is $12.6 \mathrm{~cm} / \mathrm{s}$ and the standard deviation is $0.4 \mathrm{~cm} / \mathrm{s}$.

In the mid-basin and the eastern wedge, most of the northward flow is found in the upper $1000 \mathrm{~m}$. 


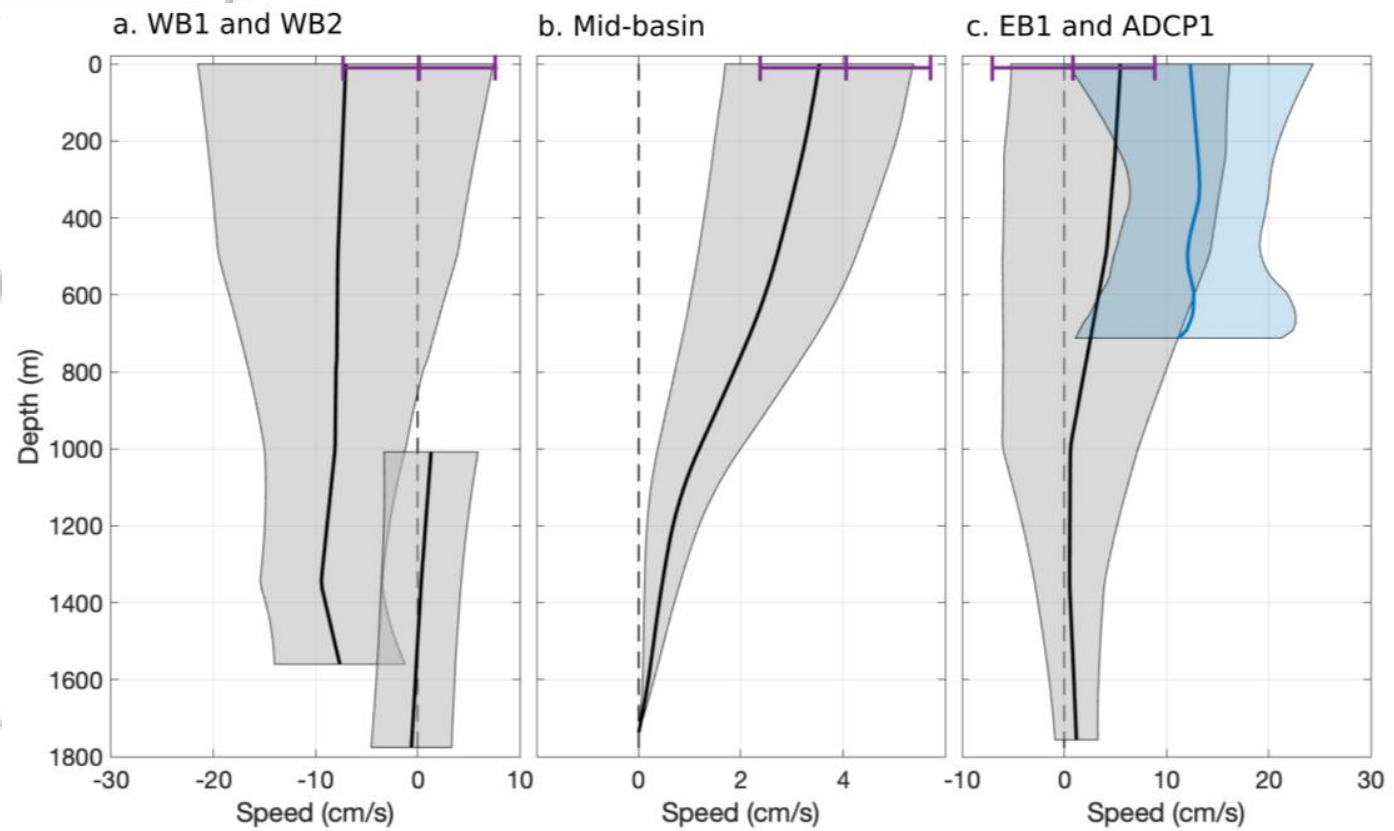

Figure 3: Four-year mean ( \pm one standard deviation) of the 25-day low-pass northward currents for (a) WB1 and WB2, (b) the dynamic height moorings and (c) EB1 with ADCP1. The 8-month mean northward current from ADCP1 is indicated in blue (Nov. 2014 - Jun. 2015). The horizontal purple line in each panel indicates the mean \pm one standard deviation of the northward surface absolute geostrophic current from altimetry (L4 gridded product), calculated over the same time-period (Text S2).

\subsubsection{Mean transports and variability}

A surprising feature revealed by the Rockall Trough mooring array is the large range of the total transport (24.7 Sv), spanning from -7.4 Sv to 17.3 Sv in the 40h low-pass filtered time-series. The total transport variability is dominated by the mid-basin and western wedge transport time-series (Figure 4). To focus attention on sub-annual and inter-annual time-scales, we used a third-order Butterworth filter with a cutoff period of 90 days to filter the transport time-series following (Bower \& von Appen 2008). For the rest of this study, we focus on the 90-day low-pass filtered transport time-series, which spans from -1.6 Sv to $9.1 \mathrm{~Sv}$ (10.7 Sv).

The total transport across the section is mainly northward, with a mean \pm one standard deviation of $4.5 \pm 2.3 \mathrm{~Sv}$ and a standard error on the mean (SE) of $0.8 \mathrm{~Sv}$. The Ekman transport calculated along the section varies 
from $-0.93 \mathrm{~Sv}$ to $0.25 \mathrm{~Sv}$, with a mean \pm one standard deviation of $-0.20 \pm 0.21 \mathrm{~Sv}$. This is an order of magnitude smaller than the total transport (Figure 4a), and therefore the Ekman transport is considered as a negligible contribution to the net meridional transport and is not included.

On average, the flow is southward in the western wedge $(-2.0 \pm 1.9 \mathrm{~Sv}, \mathrm{SE}$ : 0.4 Sv), northward in the mid-basin (5.2 $\pm 2.4 \mathrm{~Sv}, \mathrm{SE}: 0.7 \mathrm{~Sv}$ ) and northward in the eastern wedge (1.4 $\pm 1.1 \mathrm{~Sv}, \mathrm{SE}: 0.3 \mathrm{~Sv}$ ) (Figure 4b,4c, Table 1).
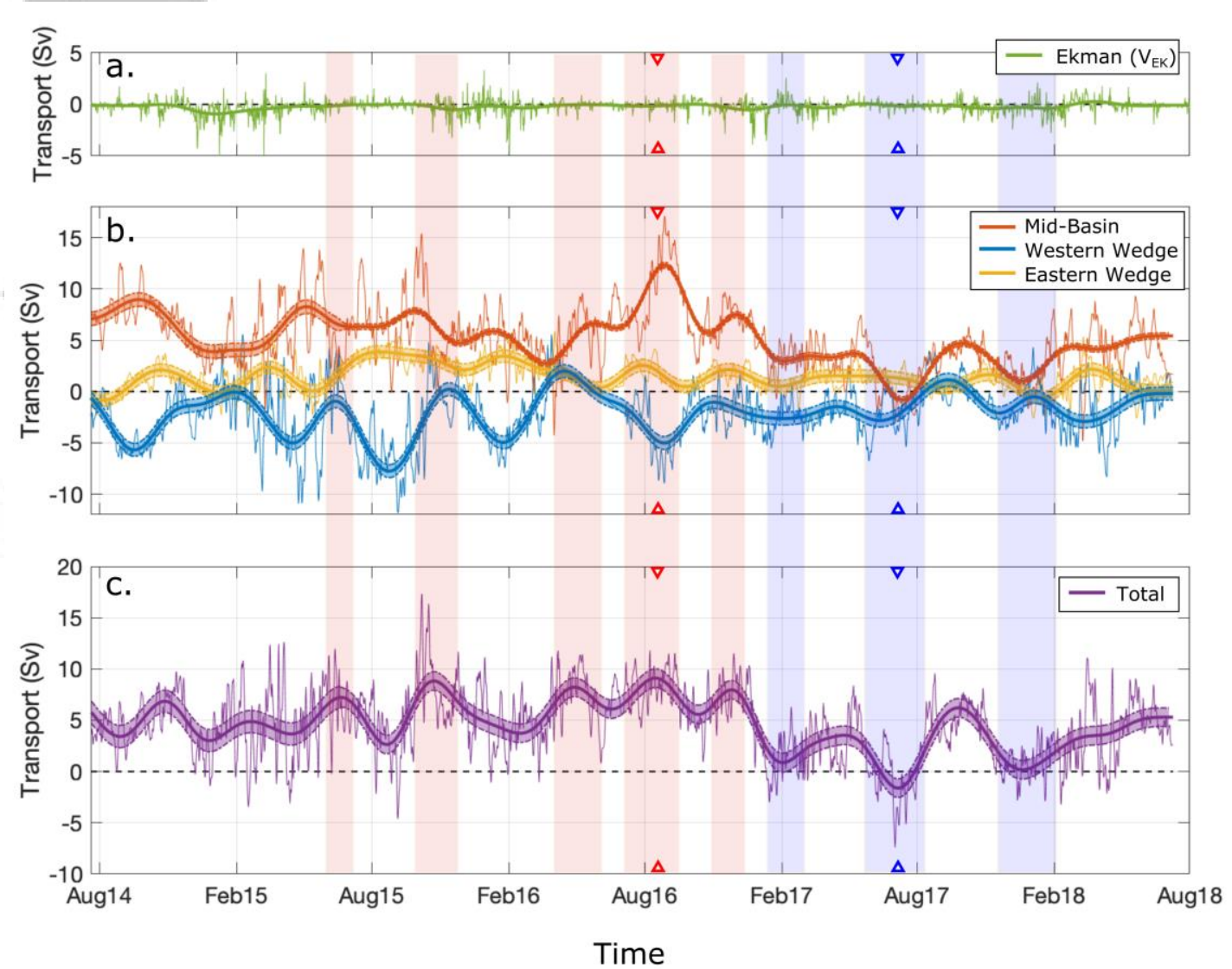

Figure 4: Time-series of 40-hour (thin lines) and 90-day (thick lines) low-pass filtered transport for: (a) the meridional component of the Ekman transport, (b) the eastern wedge, western wedge and mid-basin, and (c) for the whole section. Shaded areas correspond to the accuracy of the different time-series ( \pm one RMS error, see section 4 for more details). Extrema in transport are indicated by triangle markers on top of the subpanels (the maximum on 15 August 2016 is in red, and the minimum on 06 July 2017 is in blue). The blue/red shaded areas indicate periods of low/high transport, defined as when the total transport is inferior/superior to the mean transport \pm one standard deviation.

The transport maximum in the Rockall Trough is in August 2016 (9.1 Sv), due to an extreme northward transport in the mid-basin (12.3 Sv) (Figure 4b, Figure S3). The total transport minimum is in July 2017 (-1.6 Sv), associated with the lowest 
mid-basin transport recorded during the 4-years of measurement (-0.8 Sv, Figure 4b, Figure S3).

In order to characterize the vertical and horizontal structure of the transport during periods of high or low northward transport in the Rockall Trough, we define two composites-states. For the high transport composite, we average together all the periods when the total transport was greater than the mean plus one standard deviation (red shaded areas on Figure 4). For the low transport composite, we average together all the periods where the total transport was lower than the mean minus one standard deviation (blue shaded areas on Figure 4). Each composite-period represents $15 \%$ of the 4 -year record. The total transport (mean \pm one standard deviation) is $7.8 \pm 1.0 \mathrm{~Sv}$ for the high transport period and $0.6 \pm 0.6 \mathrm{~Sv}$ for the low transport composite (Table 1). The high transport composite is associated with a higher northward transport in the mid-basin $(7.3 \mathrm{~Sv})$ and in the eastern wedge $(2.0 \mathrm{~Sv})$, as seen on Figure 5. The low transport state is associated with a weaker northward transport in the mid-basin $(1.8 \mathrm{~Sv})$ and in the eastern wedge $(0.6 \mathrm{~Sv})$. The western wedge transport (mean \pm one standard deviation) is not different during the periods of high and low transport, $-1.5 \pm 0.7 \mathrm{~Sv}$ and $-1.8 \pm 0.3 \mathrm{~Sv}$ respectively. 
Table 1: Statistics of the 90-day low-pass filtered transport time-series for the 2014-2018 period: SD: standard deviation, SE: Standard error; ITS: Integral Time Scale (measure of the correlation length), EDOF: Effective Degree Of Freedom calculated from the ITS (for 90-day low-pass filtered time-series). ITS is calculated as twice the area of the positive autocorrelation function from zero to the first zero crossing. Mean and standard deviation for the high [HI] and low [LO] transport-composite states are also indicated.

\begin{tabular}{|c|c|c|c|c|c|c|c|c|c|c|c|c|}
\hline & Mean & SD & SE & Min & Max & Range & ITS & EDOF & {$[\mathrm{HI}]$} & & [LO] & \\
\hline & 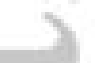 & & & & & & & & Mean & SD & Mean & SD \\
\hline Y & (Sv) & (Sv) & (Sv) & (Sv) & (Sv) & (Sv) & (days) & & (Sv) & (Sv) & (Sv) & (Sv) \\
\hline Total & 4.5 & 2.3 & 0.8 & -1.6 & 9.1 & 10.7 & 150.1 & 9.7 & 7.8 & 1.0 & 0.6 & 0.6 \\
\hline WW & -2.0 & 1.9 & 0.4 & -7.8 & 2.0 & 9.8 & 61.6 & 24.4 & -1.5 & 0.7 & -1.8 & 0.3 \\
\hline MB & 5.2 & 2.4 & 0.7 & -0.8 & 12.3 & 13.1 & 138.1 & 10.5 & 7.3 & 0.7 & 1.8 & 0.4 \\
\hline EW & 1.4 & 1.1 & 0.3 & -0.9 & 3.9 & 4.8 & 146.7 & 10.2 & 2.0 & 0.3 & 0.6 & 0.2 \\
\hline
\end{tabular}
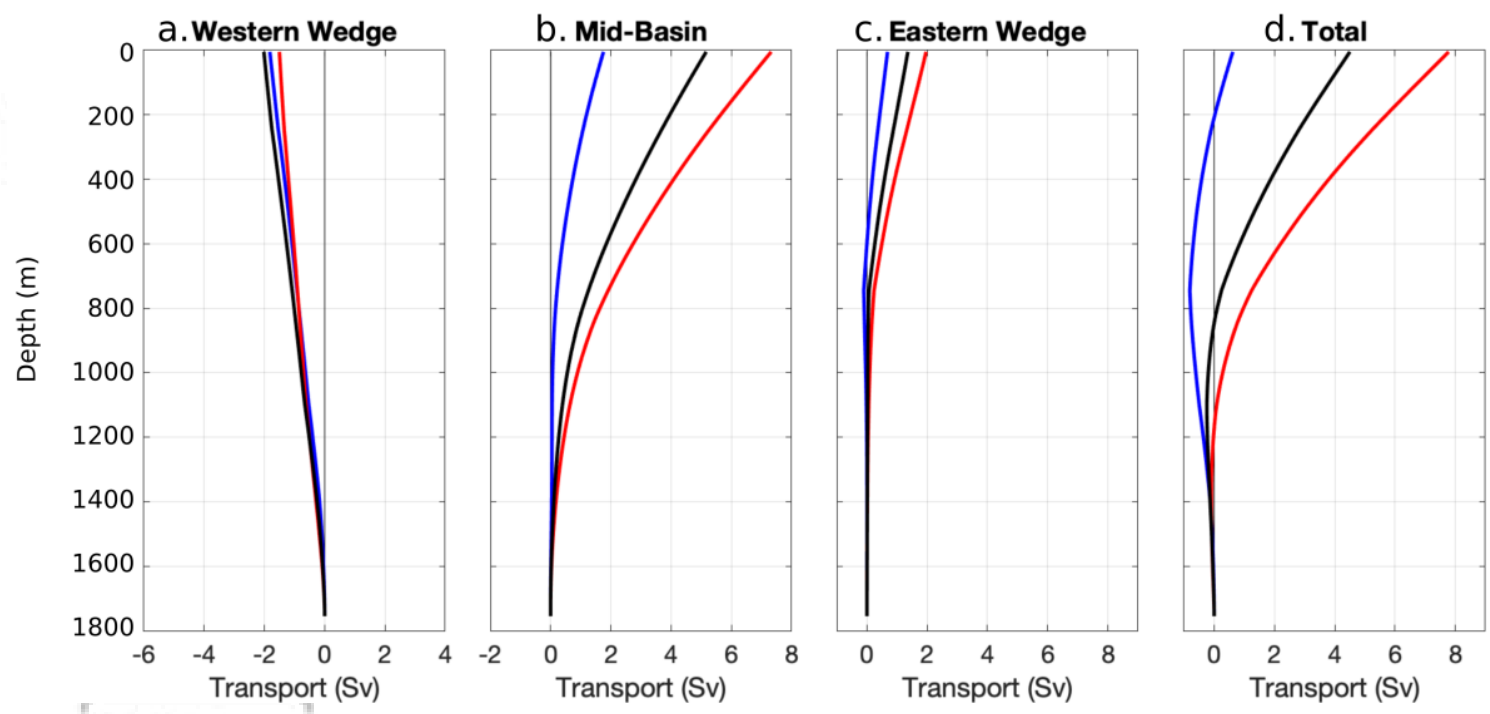

Figure 5: Cumulative transport integrated from $1760 \mathrm{~m}$ to the surface for: (a) the western wedge, (b) the mid-basin, (c) the eastern wedge and (d) the whole section. The black line corresponds to the 4-year mean, whilst the coloured lines show the mean for the period of low transport (inferior to the mean - one standard deviation, blue) and the period of high transport (superior to the mean + one standard deviation, red). Cumulative transport at the time of the maximum and minimum Rockall Trough transports are shown on Figure S3. 


\subsubsection{Trends and Seasonal Cycles}

For the 2014-2018 period, the mid-basin component has a significant downward trend in transport of $-1.0 \mathrm{~Sv} /$ year $(95 \%$ confidence interval of $[-2.0,0.0]$ Sv/year, see Table 2), explaining $23 \%$ of the variance in the transport time-series. No significant downward linear trends (both lower and upper limits of the $95 \%$ confidence interval are negative) were detected in the western or eastern wedge transport time-series.

Seasonal cycles were calculated for each component of the array as the monthly average of the detrended time-series. The ranges of the seasonal cycle are 2.4 Sv in the western wedge, 3.5 Sv in the mid-basin and $1.2 \mathrm{~Sv}$ in the eastern wedge (Table 2) and account for, respectively, $24 \%, 27 \%$, and $25 \%$ of the range of variability observed in the 90-day low-pass filtered time-series (Table 1).. The seasonal cycles have two maxima found during fall (Sep.-Dec.) and spring (Mar.-May) and two minima found in winter (Jan.-Feb.) and in summer (Jun.-Aug) (Figure 6, Table 2).

The standard error of the monthly seasonal mean is maximum at the end of the summer (August-September); it varies from $0.1 \mathrm{~Sv}$ (March) to $0.5 \mathrm{~Sv}$ (September) for the total transport time-series, $0.1 \mathrm{~Sv}$ (July) to $0.6 \mathrm{~Sv}$ (September) for the western wedge, $0.1 \mathrm{~Sv}$ (October) to $0.4 \mathrm{~Sv}$ (August) for the mid-basin, and $0.0 \mathrm{~Sv}$ (November) to $0.3 \mathrm{~Sv}$ (August) for the eastern wedge. 
Table 2: Trend and seasonal cycle extrema for the observed transport time-series (90-day low-pass filtered) calculated for the total transport time-series (TOT), the western wedge (WW), the mid-basin (MB) and the Eastern Wedge (EW). The standard error (SE) is calculated for each month as the monthly standard deviation divided by the square root of the degree of freedom.

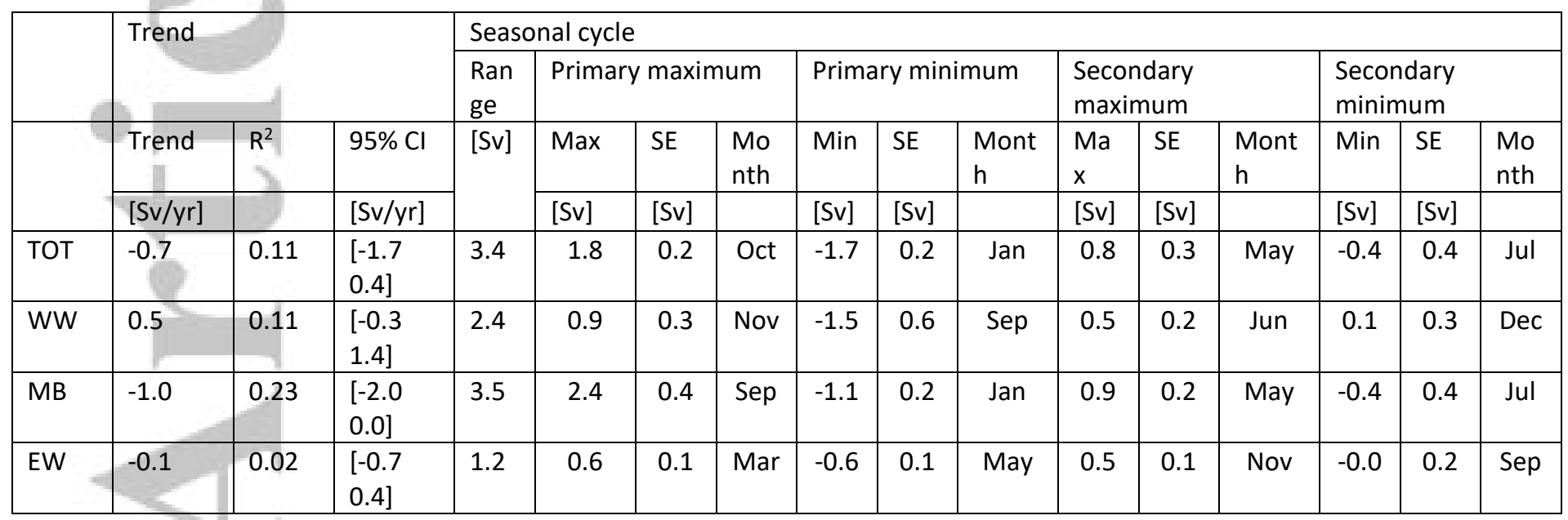



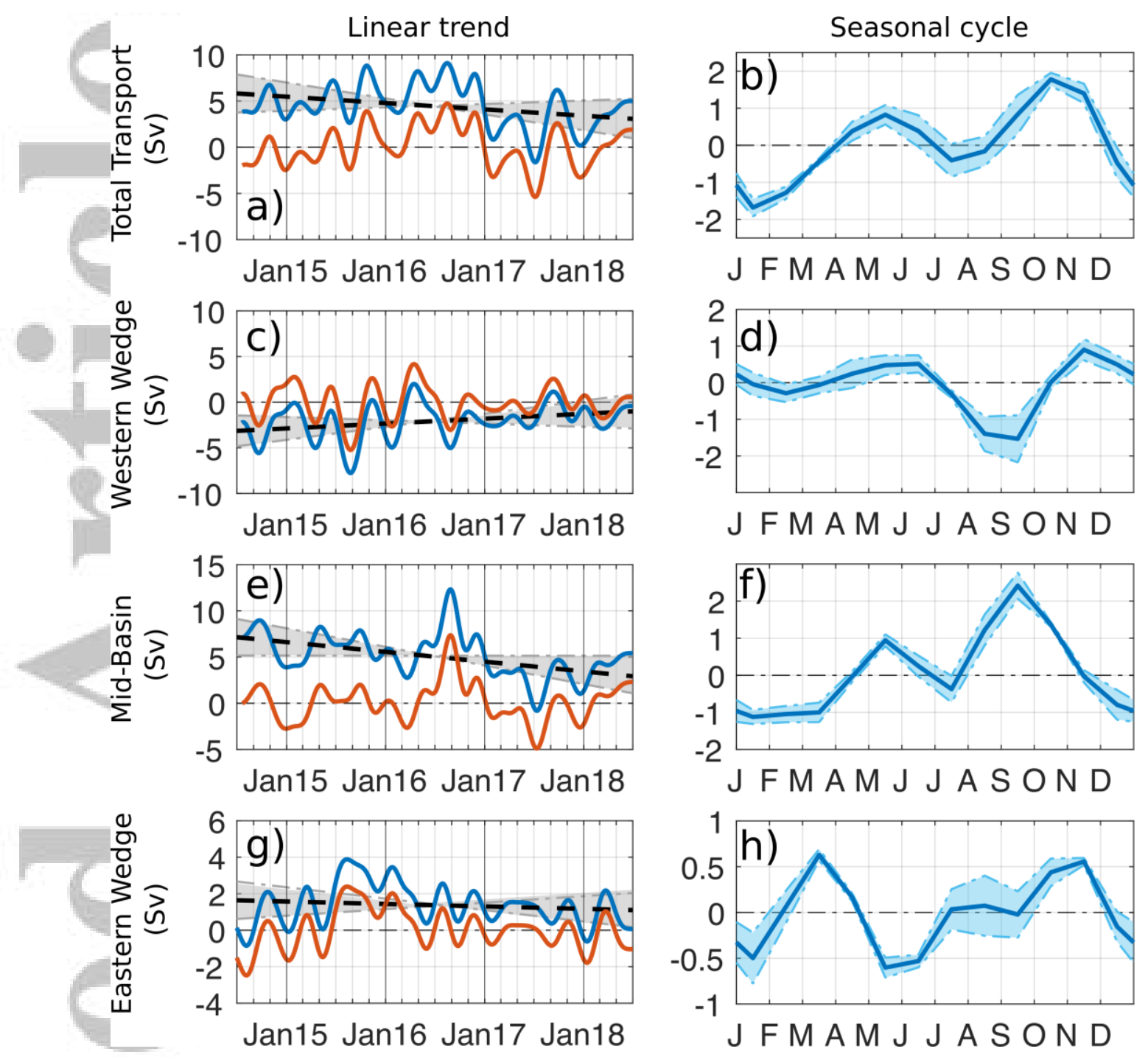

Figure 6: Linear trend (a, c, e, g) and seasonal cycle (b, d, f, h) for the total, western wedge, mid-basin and eastern wedge transports. In the left subpanels, trends (black dashed lines) are calculated by fitting a line to the transport time-series (blue lines), the grey shaded area represents the 95\% confidence intervals for the linear trend. Detrended time-series are plotted in orange. Trends and confidence intervals are indicated in Table 2. Seasonal cycles calculated as the monthly average of the detrended data are shown in the right subpanels. The light blue shaded area shows the monthly mean \pm one standard error (standard deviation divided by the square root of the degree of freedom).

\subsection{Large-scale circulation changes associated with high and low transport regimes}

The mesoscale variability in the subpolar North Atlantic and the intensity of the eddy activity represented by the EKE has been documented in several studies. At midlatitudes away from topography, and particularly in the North Atlantic, areas of 
high EKE are associated with energetic currents. Therefore, changes in the patterns of EKE can be indicative of changes in the strong current systems (Chafik et al., 2014; Heywood et al., 1994; Reverdin et al., 2003; Volkov, 2005). Using surface EKE computed from satellite altimetry between 2014 and 2018, we consider whether there are characteristic spatial patterns of EKE associated with the high and low transport states defined by the mooring data.

The 90-day low-pass filtered EKE fields, absolute surface geostrophic currents and ADT are shown in Figure 7 for periods of low and high transport (snapshots at transport minimum and maximum in July 2017 and August 2016 respectively are shown on Figure S4). EKE reaches $200 \mathrm{~cm}^{2} / \mathrm{s}^{2}$ in the Rockall Trough in both composite-states (Figure 7). During the low-transport period, EKE is organized around eddy-like structures centred on $12^{\circ} \mathrm{W}, 56^{\circ} \mathrm{N}$. During the high-transport period a strong NAC jet, characterised by an elevated EKE-band, stretches from the entrance of the Rockall Trough to north of the array $\left(\sim 59^{\circ} \mathrm{N}\right)$.

During periods of low transport, there is a westward shift of the $-0.1 \mathrm{~m}$ ADT contour (Figure 7a). In contrast, during the high-transport period and the 2014-2018 period, the mean $-0.1 \mathrm{~m}$ contour is located east of Rockall Bank in the Rockall Trough (Figure 7b). We note that when considering the 2014-2018 mean, the -0.1 m contour is similarly located (Figure S1). However, the location of the $0 \mathrm{~m}$ ADT contour is similar during both the high and low transport times, meaning that the zonal gradient of ADT in the Rockall Trough is reduced during the period of low transport and increased for periods of high transport. This agrees well with the reduction of the mid-basin geostrophic transport observed during the low-transport period (Figure $4 \mathrm{~b}$ ). The westward shift of the $-0.1 \mathrm{~m}$ contour is even larger at the time of the Rockall Trough transport minimum (Jul. 2017, Figure S4), when it reached $20^{\circ} \mathrm{W}$ in the Iceland Basin.

Other regional circulation changes occur during the low transport periods, such as the retroflection of the NAC at the entrance of the Trough (Figure 7a and Figure S4a), and the presence of an eastward flow between George Bligh Bank and Lousy Bank $\left(60^{\circ} \mathrm{N}, 13.5^{\circ} \mathrm{W}\right)$. In contrast, during the high transport period, the NAC can be distinguished as a continuous flow into the Rockall Trough along $12^{\circ} \mathrm{W}-13^{\circ} \mathrm{W}$. During the period of high-transport (Figure 7b, Figure S4b) and on the 4-year mean map (Figure S1), the NAC appears to separate into several 
eastward-propagating sub-branches. These eastward flows can be seen south and north of the Anton Dohrn seamount $\left(57^{\circ} \mathrm{N}\right.$ and $58.5^{\circ} \mathrm{N}$ ) and south of Bill Bailey Bank $\left(60^{\circ} \mathrm{N}\right)$. During the high-transport period, an additional NAC sub-branch can be seen flowing northward between Lousy Bank and Bill Bailey Bank (Figure 7b). 
a. Composite Low

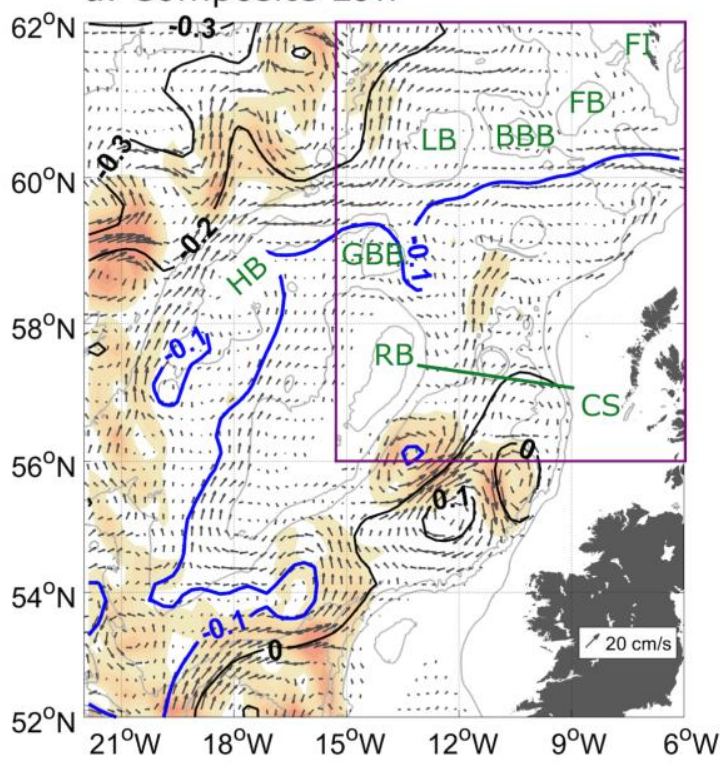

b. Composite High

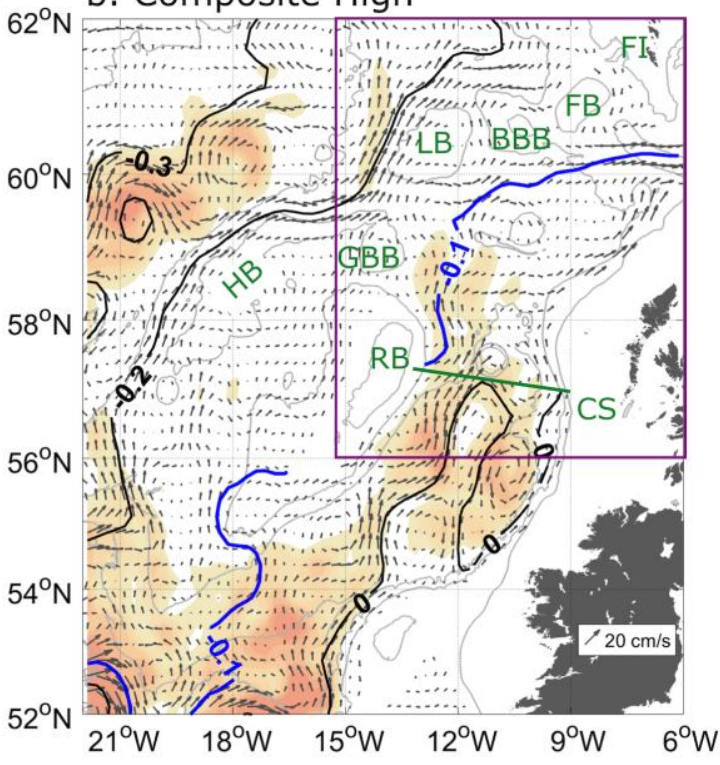

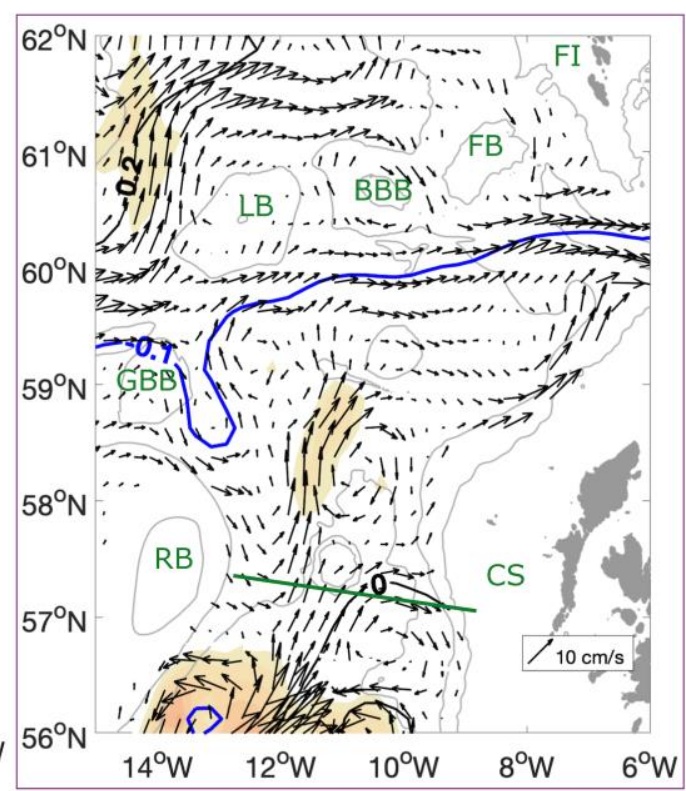

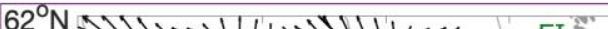

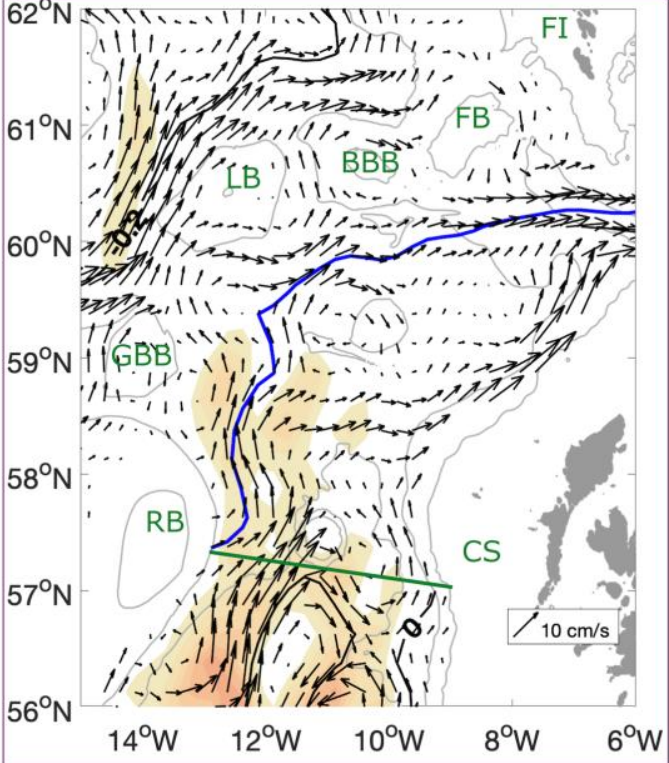

\section{$60 \quad 80100120140160180200$ \\ $\operatorname{EKE}\left(\mathrm{cm}^{2} / \mathrm{s}^{2}\right)$}

Figure 7: 90-day low-pass filtered EKE (color scale) and surface absolute geostrophic currents (black arrows) for the composite-periods of: (a) low and (b) high transports. Data are plotted for water depths greater than $400 \mathrm{~m}$ and velocities exceeding $2.5 \mathrm{~cm} / \mathrm{s}$. The green line near $57.5^{\circ} \mathrm{N}$ indicates the Rockall Trough mooring array. Mean absolute dynamic topography contours are plotted as thick black lines with a contour interval of $0.1 \mathrm{~m}$, with the $-0.1 \mathrm{~m}$ contour in blue. Bathymetry from ETOPO are shown in grey for the 200, 1000, 2000, and 3000-m contours. Acronyms: eddy kinetic energy (EKE); Earth TOPOgraphic database (ETOPO); other acronyms defined in Figure 1. EKE and surface absolute 
geostrophic current at the time of the minimum and maximum transport are shown in supplementary material (Figure S4).

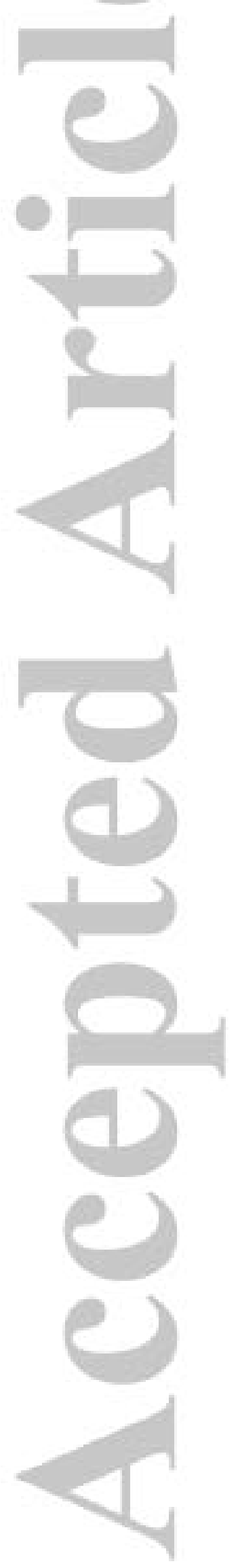




\section{Discussion}

From four years of UK-OSNAP mooring data we have quantified and described the variability of the Rockall Trough transport, giving the first continuous multi-year measurements. The west and east boundary currents are measured directly using current meters, while the CTDs on moorings WB1/2 and EB1 are used to compute dynamic height profiles in order to calculate the mid-basin geostrophic transport. We show that the design of the mooring array is fit for purpose; methodological and instrumental errors give a mean bias error of $0.03 \mathrm{~Sv}$ and a root mean square error of $0.93 \mathrm{~Sv}$ on a mean total transport of $4.5 \mathrm{~Sv}$.

There is an observing gap in the shelf edge current (east of $9.6^{\circ} \mathrm{W}$ ); the bottom-mounted ADCP within a trawl-resistant frame suffered heavy fishing-related damage on multiple deployments. Due to repeated instrument losses, we used GLORYS12v1 (1/12 ${ }^{\circ}$ global ocean reanalysis) to recreate velocity time-series at the location of the ADCP mooring. The reanalysis was able to reproduce the correct vertical structure of the 4-year mean current profiles at the mooring sites but had a bias of $-7.6 \mathrm{~cm} / \mathrm{s}$ compared to the mean velocity of a successful 8-month ADCP deployment which we accounted for. The error of the model-based reconstruction of the shelf edge current transport was assessed by applying the same methodology on repeated EEL LADCP sections and comparing it to the actual LADCP velocity field. We note that the uncertainty associated with our method for estimating the shelf edge current (mean bias error of $0.2 \mathrm{~Sv}$ and RMS error of $0.6 \mathrm{~Sv}$, Table S1) is small compared to the transport and variability in the mid-basin and in the western Rockall Trough. A new observing strategy has been adopted from 2020 onwards, replacing the ADCP mooring with a repeated glider survey.

Our new transport estimates agree with previously published work. Although we used a slightly different methodology, the mean for the first 21 months $(5.1 \mathrm{~Sv})$ closely matches the NAC transport in the Rockall Trough calculated by Lozier et al. (2019): 5.2 Sv flowing east of $13.0^{\circ} \mathrm{W}$ for the layer $\sigma_{0}<27.66 \mathrm{~kg} / \mathrm{m}^{3}$. The 4 -year mean total meridional transport measured in the Rockall Trough (4.5 Sv, standard error of $0.8 \mathrm{~Sv}$ ) is in the range of previous $\mathrm{EEL}$ hydrographic estimates: $3.7 \pm 2.4 \mathrm{~Sv}$ for 1975-1998 (Holliday et al., 2000) and 3.0 \pm 3.7 Sv for 1997-2014 (Holliday et al., 
2015). However, these previous estimates used a mid-depth level of no motion, and our new direct current measurements in the boundaries show significant barotropic flows, particularly east of the Rockall Bank where a 4-year mean southward flow of -2.0 Sv was observed. Similar barotropic and bathymetrically steered flows have been observed further west from repeated glider observations, on the western and eastern flanks of the Rockall Hatton Basin (Houpert et al., 2018). Work is ongoing to quantify the barotropic component of the flow between Iceland and Scotland by revisiting historical hydrographic sections and referencing the geostrophic shear to direct current measurements from ship-mounted ADCP and LADCP.

A new result from the Rockall Trough mooring array is the strong intra-annual and seasonal variability in the total transport. The 90-day low-pass filtered transport time-series has a range of 10.7 Sv, varying from 9.1 Sv in August 2016 to $-1.6 \mathrm{~Sv}$ in July 2017. The continuous observations allow us to calculate the seasonal cycle of the Rockall Trough transport. With an amplitude of 3.6 Sv during the 2014-2018 period, the seasonal cycle of the Rockall Trough transport accounts for $33 \%$ of the range of variability observed in the 90-day low-pass filtered time-series. This estimate is three times higher than that found from hydrographic data by Gary et al. (2018), albeit with the same periods for the transport extrema (maximum in spring and fall; minimum in summer and winter). As mentioned by Gary et al. (2018), their seasonal cycle is partly masked by mesoscale eddies, interannual variability and observational aliasing, which can explain the amplitude difference with our estimate.

A key finding is the occurrence of states of high and low transport in the Rockall Trough which appear to be related to changes in the NAC circulation. During the high transport state, the total transport is $7.8 \pm 1.0 \mathrm{~Sv}$ and during the low transport state the total transport is $0.6 \pm 0.6 \mathrm{~Sv}$, with associated changes in the mid-basin geostrophic transport. During the low-transport period, the western wedge transport (-1.8 Sv) entirely compensates the mid-basin geostrophic transport (1.8 Sv) and the net transport reflects the eastern wedge transport. During the low-transport state, EKE is organized around eddy-like structures while during the high-transport state, a strong NAC jet, characterised by an elevated EKE-band, stretches from the entrance of the basin to north of the array. We identified other regional circulation changes associated with the low-transport state, including the retroflexion of the NAC at the entrance of the Trough, and the presence of an eastward flow between 
George Bligh Bank and Lousy Bank. A similar shift between two states of variability was found in the Iceland Basin by Zhao et al. (2018). They found that alternating eddy and front patterns in the eastern Iceland Basin contribute significantly to the total poleward heat transport variability on time scales from sub-seasonal to interannual. Chafik et al. (2014) found that sea surface height (SSH) slopes from satellite altimetry vary out of phase west and east of the Hatton Bank: a decrease in the SSH slope west of the Hatton Bank appears to be compensated by an increase of the SSH slope east of the Hatton Bank, and vice versa. More studies are needed to quantify the relationship between the NAC variability between the Iceland Basin and the Rockall Trough (e.g. are the high-transport states in the Rockall Trough associated with low-transport states in the Iceland Basin?), and to understand the nature of these "modes" of NAC variability (atmospherically-forced response vs chaotic).

Holliday et al. (2020) reported a dramatic change in the properties of the upper waters of the North Atlantic in 2014-2016, likely due to a change of the mean wind stress curl pattern over the region and a much intensified subpolar gyre (Hátún \& Chafik, 2018). These changes in water mass properties, and an eastward shift of the subpolar front, would be consistent with our findings of an increased northward transport in the Rockall Trough during the 2014-2016 period. A significant decrease in the mid-basin and total transport occurs between December 2016 and February 2017 (Figure 4). After January 2017 the mean Rockall Trough transport reduced from 5.7 Sv to 2.7 Sv. The SSH gradient was reduced in the eastern subpolar North Atlantic during 2017, which could explain the decrease in transport observed in the Rockall Trough after January 2017, however, further work is needed to better understand the links between the Rockall Trough transport variability and regional circulation changes.

The northward transport of the NAC through the Rockall Trough (6.6 Sv) is larger than previously thought and mostly takes place in the Rockall Trough interior, not via the shelf edge current. Satellite altimetry shows that the mean position of the NAC branch (2014-2018) is west of the Anton Dohrn Seamount between $13^{\circ} \mathrm{W}$ and $11^{\circ} \mathrm{W}$ (Figure S1). This is also seen on the mean EEL LADCP section (Figure 2), where a northward flow between Rockall Bank and the Anton Dohrn seamount is superimposed on an anticyclonic recirculation around the seamount. Satellite 
altimetry also shows that this main NAC branch is not completely independent of the branch flowing along the shelf edge. As the mid-basin NAC branch propagates northward it seems to be "leaking" water towards the east. These eastward propagating sub-branches appear to join the shelf branch before it enters the Faroe-Shetland Channel (Figure S1, Figure 1). The net transport across the Rockall Trough array is $2 \mathrm{~Sv}$ lower than the total northward transport because of the presence of a southward flow east of the Rockall Bank. The mechanisms driving this flow are not fully understood yet, but some evidence exists for a significant recirculation of the "Icelandic" NAC branch around the Rockall Plateau region (encompassing the Hatton Bank, Hatton-Rockall Basin and Rockall Bank). For example, Gary et al. (2018) used the time-mean barotropic streamfunction from the ocean model VIKING20 and showed that a 2 Sv anticyclonic recirculation exists around the Rockall Plateau. Howe et al. (2001) identified a zone of active seabed erosion extending from George Bligh Bank to the south of Rockall Bank, between $1000 \mathrm{~m}$ and $1500 \mathrm{~m}$ depth, indicating vigorous bottom-current activity. Initially associated with the Wyville Thomson Overflow Water, we think that this erosion pattern could also be the imprint of the strong barotropic currents associated with the NAC recirculating around the Rockall Plateau.

Our results, along with those of Lozier et al. (2019) contrast with a recent review by Bower et al. (2019) who concluded that $90 \%$ of the total northward upper limb AMOC transport was associated with the NAC in the Iceland Basin, and that the Rockall Trough was a negligible pathway. This statement builds on three other studies mostly based on the OVIDE oceanographic section (Daniault et al., 2016; Mercier et al., 2015; Sarafanov et al., 2012). In these studies, the authors acknowledge that their studies are representative of the $2002-2012$ period, when the atmospheric forcing and the subpolar gyre were at their weakest. Therefore, one explanation for the differences between these historical and our new study could be a time-dependent partitioning of northward transport between the Iceland Basin and Rockall Trough. A further explanation could be the existence of subsurface pathways connecting the Iceland Basin and the Rockall Trough. The presence of these pathways could explain the fate of the mean northward flow of $1.8 \mathrm{~Sv}$ found between $650 \mathrm{~m}$ and $1800 \mathrm{~m}$ in the mid-basin. North of the mooring array, the only exit pathways deeper than 650 m are the 1100 m deep channel found between Rockall 
Bank and George Bligh Bank, and the 1200 m deep channels located between George Bligh Bank, Lousy Bank and Bill Bailey Bank (Figure 1). Pollard et al. (2004) showed from a survey in 1996 that $2 \mathrm{~Sv}$ of saline water exited the Rockall Trough between Rockall Bank and Lousy Bank. Sarafanov et al., (2012) combined multiple annual hydrographic measurements (2002-2008) with satellite altimetry and found that $10.4 \mathrm{~Sv}$ is transported by the NAC across $59.5^{\circ} \mathrm{N}$ between $17^{\circ} \mathrm{W}$ and $4^{\circ} \mathrm{W}$, in the upper-layer $\left(\sigma_{0}<27.55 \mathrm{~kg} / \mathrm{m}^{3}\right)$. They found a maximum in the NAC transport centred north of the Rockall Trough at $59.5^{\circ} \mathrm{N} / 14{ }^{\circ} \mathrm{W}$, between George Bligh Bank and Lousy Bank. Further work is needed to characterize and quantify the NAC pathways connecting the Rockall Trough, the Iceland Basin and the Nordic Seas.

\section{Conclusions}

The first multi-year continuous measurements of the Rockall Trough transport reveal a 4-year mean net flow of $4.5 \mathrm{~Sv}$. A NAC branch in the mid-basin transports 5.2 Sv northward and $1.4 \mathrm{~Sv}$ is transported northward in the Scottish shelf edge current. These pathways represent around half the net northward transport of warm water of the upper-limb of the AMOC measured through the OSNAP array (Lozier et al., 2019). A 4-year mean southward flow of -2.0 Sv was observed in the western part of the Rockall Trough, part of a wider anticyclonic recirculation around the Rockall Bank.

For the first time we have characterized the seasonal variability in the Rockall Trough transport using 4-years of continuous measurements. The 90-day low-pass filtered transport time-series has a range of $10.7 \mathrm{~Sv}$, varying from $9.1 \mathrm{~Sv}$ in August 2016 to $-1.6 \mathrm{~Sv}$ in July 2017. With an amplitude of $3.6 \mathrm{~Sv}$ during the 2014-2018 period, the seasonal cycle of the Rockall Trough transport accounts for $32 \%$ of the range of variability observed in the 90-day low-pass filtered time-series. The greatest transport is found in fall (October) while the smallest is found in winter (January).

There is a detectable seasonal signal for the western wedge, the mid-basin, eastern wedge, and the total Rockall Trough transport time-series. The seasonal cycles have two maxima found during fall (Sep.-Dec.) and spring (Mar.-May) and two minima found in winter (Jan.-Feb.) and in summer (Jun.-Aug) (Figure 6, Table 2). 
A new finding is the description of two states of high and low transport in the Rockall Trough which appear to be related to changes in the NAC circulation. During the low-transport state, EKE is organized around eddy-like structures while during the high-transport state, a strong NAC jet, characterised by an elevated EKE-band, stretches from the entrance of the basin to north of the array. We also identified other regional circulation changes associated with the low-transport state, including the retroflexion of the NAC at the entry of the Trough, and the presence of an eastward flow between George Blight Bank and Lousy Bank. 


\section{Appendix}

\section{Appendix A: Referencing the mid-basin geostrophic shear to altimetry}

One possible method to estimate transport in the mid-basin is to reference the geostrophic velocities to Absolute Dynamic Topography (ADT) from satellite altimetry. To assess the suitability of this approach, we compared the ADT anomalies at the location of moorings WB1 and EB1 to Steric Height $(\mathrm{SH})$ anomalies calculated from those moorings (Figure A1 a,b).

Although the overall agreement between the time-series of $\mathrm{SH}$ and gridded ADT anomalies is reasonable at both locations, the mean difference is higher at WB1 (mean \pm standard deviation, $0.18 \pm 3.56 \mathrm{~cm})$ compared to EB1 $(-0.02 \pm 1.88 \mathrm{~cm})$. Additionally, several mismatches between the two time-series exist, particularly at WB1 (e.g. October 2015). These non-negligible differences between ADT and SH induce strong transport anomalies of up to $10 \mathrm{~Sv}$ when the ADT is used to reference the mid-basin geostrophic velocity (Figure A1 c,d).

To investigate possible reasons for this discrepancy, we compared the gridded ADT product to the data from individual satellite tracks (Figure A1). At WB1, periods of ADT and $\mathrm{SH}$ mismatches correspond to periods when only a few satellite tracks are close to the mooring site (only Altika and Cryosat missions with a periodicity of 35 and 29 days). In contrast, at EB1, which is located on the Jason track 113 (periodicity of 10 days), the differences are smaller. Over the period 2014-2017, the mean \pm standard deviation of the difference between the along-track and gridded ADT at the mooring locations are $0.6 \pm 2.7 \mathrm{~cm}$ at EB1 and $-2.3 \pm 3.9 \mathrm{~cm}$ at WB1. This raises doubt on the quality of the gridded ADT time-series at the WB1 location.

By defining the uncertainty of the gridded ADT as the standard deviation of the difference between the along-track and gridded ADT data, we find a mean slope error of $5.0 \mathrm{~cm}\left(\sqrt{2.7^{2}+3.9^{2}}\right)$, equivalent to a transport error of $6.8 \mathrm{~Sv}$.

The introduction of this large mean error, and the lack of a regular satellite track close to WB1 before 2017, meant that we chose not to reference our mid-basin geostrophic velocities to satellite altimetry. 


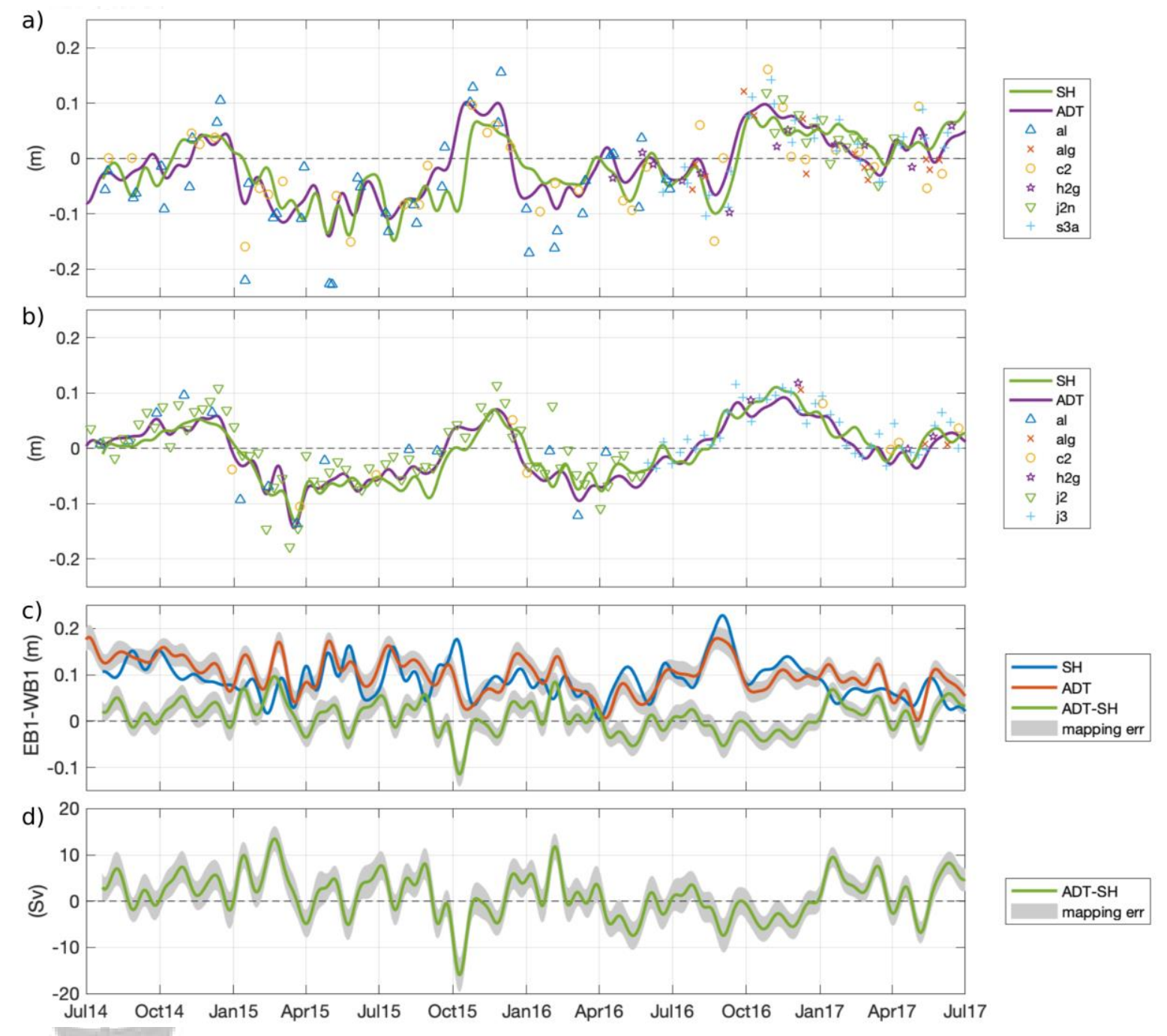

Figure A1: Anomaly (mean removed) of 25 day low-pass filtered Steric Height, calculated from $1760 \mathrm{~m}$ to the surface, and anomalies of Absolute Dynamic Topography from gridded and along-track data at (a) WB1 and (b) EB1. For each individual satellite track, the closest along-track data point in a radius of $15 \mathrm{~km}$ from the mooring location is kept. Acronyms for satellite missions: al: Altika; alg: Altika Drifting phase; c2: Cryosat-2; h2g: Haiyang-2A Geodetic Phase; j2: Jason-2; j2n: Jason-2 Interleaved; j3: Jason-3; s3a: Sentinel-3A. ; (c) Surface slope between EB1 and WB1 due to SH, ADT and the difference betwen the two; (d) Transport between $E B 1$ and WB1 due to the difference in the SH and ADT slopes. 


\section{Acknowledgments and Data Availability}

This analysis is a contribution to UK NERC National Capability programmes the Extended Ellett Line and CLASS (NE/R015953/1), and NERC grants UK OSNAP (NE/K010875/1, NE/K010875/2 ,NE/K010700/1) and UK OSNAP Decade (NE/T00858X/1, NE/T008938/1). CJ has received funding from the European Union's Horizon 2020 Research and Innovation Programme under grant agreement no. 678760 (ATLAS). This output reflects only the author's view and the European Union cannot be held responsible for any use that may be made of the information contained therein. This study has been conducted using E.U. Copernicus Marine Service Information. BODC curates the UK-OSNAP mooring data (http://dx.doi.org/10/c7qv) and the Extended Ellet Line dataset (https://www.bodc.ac.uk/resources/inventories/edmed/report/644/). Please see text and references for other data sources. The authors wish to thank Bee Berx and an anonymous reviewer for their suggestions that have improved this manuscript.

\section{References}

Berx, B., Hansen, B., Østerhus, S., Larsen, K. M., Sherwin, T., \& Jochumsen, K. (2013). Combining in situ measurements and altimetry to estimate volume, heat and salt transport variability through the Faroe-Shetland Channel. Ocean Science, 9(4), 639-654. https://doi.org/10.5194/os-9-639-2013

Bower, A., Lozier, S., Biastoch, A., Drouin, K., Foukal, N., Furey, H., et al. (2019). Lagrangian Views of the Pathways of the Atlantic Meridional Overturning Circulation. Journal of Geophysical Research: Oceans, 124(8), 5313-5335. https://doi.org/10.1029/2019JC015014

Bower, A. S., \& von Appen, W. J. (2008). Interannual variability in the pathways of the North Atlantic Current over the mid-atlantic ridge and the impact of topography. Journal of Physical Oceanography, 38(1), 104-120.

https://doi.org/10.1175/2007JPO3686.1

Chafik, L., Rossby, T., \& Schrum, C. (2014). On the spatial structure and temporal variability of poleward transport between Scotland and Greenland. Journal of 
Geophysical Research: Oceans, 119(2), 824-841.

https://doi.org/10.1002/2013JC009287

Daniault, N., Mercier, H., Lherminier, P., Sarafanov, A., Falina, A., Zunino, P., et al. (2016). The northern North Atlantic Ocean mean circulation in the early 21 st century. Progress in Oceanography, 146(July), 142-158.

https://doi.org/10.1016/j.pocean.2016.06.007

Egbert, G. D., \& Erofeeva, S. Y. (2002). Efficient Inverse Modeling of Barotropic Ocean Tides. Journal of Atmospheric and Oceanic Technology, 19(2), 183-204. https://doi.org/10.1175/1520-0426(2002)019<0183:EIMOBO>2.0.CO;2

Ellett, D. J., \& Martin, J. H. A. (1973). The physical and chemical oceanography of the Rockall channel. Deep-Sea Research and Oceanographic Abstracts, 20(7), 585-625. https://doi.org/10.1016/0011-7471(73)90030-2

Gary, S. F., Cunningham, S. A., Johnson, C., Houpert, L., Holliday, N. P., Behrens, E., et al. (2018). Seasonal Cycles of Oceanic Transports in the Eastern Subpolar North Atlantic. Journal of Geophysical Research: Oceans, 123(2), 1471-1484. https://doi.org/10.1002/2017JC013350

Häkkinen, S., \& Rhines, P. B. (2004). Decline of Subpolar North Atlantic Circulation during the 1990s. Science, 304(5670), 555-559. https://doi.org/10.1126/science.1094917

Hansen, B., Larsen, K. M. H., Hátún, H., Kristiansen, R., Mortensen, E., \& Østerhus, S. (2015). Transport of volume, heat, and salt towards the Arctic in the Faroe Current 1993-2013. Ocean Science, 11(5), 743-757. https://doi.org/10.5194/os11-743-2015

Hansen, Bogi, Østerhus, S., Turrell, W. R., Jónsson, S., Valdimarsson, H., Hátún, H., \& Olsen, S. M. (2008). The Inflow of Atlantic Water, Heat, and Salt to the Nordic Seas Across the Greenland-Scotland Ridge. In Arctic-Subarctic Ocean Fluxes (pp. 15-43). Dordrecht: Springer Netherlands. https://doi.org/10.1007/978-14020-6774-7_2

Hátún, H., \& Chafik, L. (2018). On the Recent Ambiguity of the North Atlantic Subpolar Gyre Index. Journal of Geophysical Research: Oceans, 123(8), 50725076. https://doi.org/10.1029/2018JC014101 
Hátún, Hjálmar, Sande, A. B., Drange, H., Hansen, B., \& Valdimarsson, H. (2005). Influence of the atlantic subpolar gyre on the thermohaline circulation. Science, 309(5742), 1841-1844. https://doi.org/10.1126/science.1114777

Heywood, K. J., McDonagh, E. L., \& White, M. A. (1994). Eddy kinetic energy of the North Atlantic subpolar gyre from satellite altimetry. Journal of Geophysical Research, 99(C11), 22525. https://doi.org/10.1029/94jc01740

Holliday, N. P. (2003). Air-sea interaction and circulation changes in the northeast Atlantic. Journal of Geophysical Research, 108(C8), 3259.

https://doi.org/10.1029/2002JC001344

Holliday, N. P., Pollard, R. T., Read, J. F., \& Leach, H. (2000). Water mass properties and fluxes in the Rockall Trough, 1975-1998. Deep Sea Research Part I: Oceanographic Research Papers, 47(7), 1303-1332. https://doi.org/10.1016/S0967-0637(99)00109-0

Holliday, N. P., Hughes, S. L., Bacon, S., Beszczynska-Möller, A., Hansen, B., Lavín, A., et al. (2008). Reversal of the 1960s to 1990s freshening trend in the northeast North Atlantic and Nordic Seas. Geophysical Research Letters, 35(3), L03614. https://doi.org/10.1029/2007GL032675

Holliday, N. P., Bacon, S., Allen, J., \& McDonagh, E. L. (2009). Circulation and Transport in the Western Boundary Currents at Cape Farewell, Greenland. Journal of Physical Oceanography, 39(8), 1854-1870. https://doi.org/10.1175/2009JPO4160.1

Holliday, N. P., Cunningham, S. A., Johnson, C., Gary, S. F., Griffiths, C., Read, J. F., \& Sherwin, T. (2015). Multidecadal variability of potential temperature, salinity, and transport in the eastern subpolar North Atlantic. Journal of Geophysical Research: Oceans, 120(9), 5945-5967.

https://doi.org/10.1002/2015JC010762

Holliday, N. P., Bersch, M., Berx, B., Chafik, L., Cunningham, S., Florindo-López, C., et al. (2020). Ocean circulation causes the largest freshening event for 120 years in eastern subpolar North Atlantic. Nature Communications, 11(1), 585. https://doi.org/10.1038/s41467-020-14474-y

Houpert, L., Inall, M. E., Dumont, E., Gary, S., Johnson, C., Porter, M., et al. (2018). 
Structure and Transport of the North Atlantic Current in the Eastern Subpolar Gyre From Sustained Glider Observations. Journal of Geophysical Research: Oceans, 123(8), 6019-6038. https://doi.org/10.1029/2018JC014162 Howe, J. A., Stoker, M. S., \& Woolfe, K. J. (2001). Deep-marine seabed erosion and gravel lags in the northwestern Rockall Trough, North Atlantic Ocean. Journal of the Geological Society, 158(3), 427-438. https://doi.org/10.1144/jgs.158.3.427

Huthnance, J. M. (1984). Slope Currents and "JEBAR." Journal of Physical Oceanography, 14(4), 795-810. https://doi.org/10.1175/15200485(1984)014<0795:SCA>2.0.CO;2

Johnson, C., Sherwin, T., Smythe-Wright, D., Shimmield, T., \& Turrell, W. (2010). Wyville Thomson Ridge Overflow Water: Spatial and temporal distribution in the Rockall Trough. Deep-Sea Research Part I: Oceanographic Research Papers, 57(10), 1153-1162. https://doi.org/10.1016/j.dsr.2010.07.006

Johnson, C., Sherwin, T., Cunningham, S., Dumont, E., Houpert, L., \& Holliday, N. P. (2017). Transports and pathways of overflow water in the Rockall Trough. Deep Sea Research Part I: Oceanographic Research Papers, 122, 48-59. https://doi.org/10.1016/j.dsr.2017.02.004

Lozier, M. S., Li, F., Bacon, S., Bahr, F., Bower, A. S., Cunningham, S. A., et al. (2019). A sea change in our view of overturning in the subpolar North Atlantic.

Science, 363(6426), 516-521. https://doi.org/10.1126/science.aau6592

Marsh, R., Haigh, I. D., Cunningham, S. A., Inall, M. E., Porter, M., \& Moat, B. I. (2017). Large-scale forcing of the European Slope Current and associated inflows to the North Sea. Ocean Science, 13(2), 315-335.

https://doi.org/10.5194/os-13-315-2017

McCarthy, G. D., Smeed, D. A., Johns, W. E., Frajka-Williams, E., Moat, B. I., Rayner, D., et al. (2015). Measuring the Atlantic Meridional Overturning Circulation at $26^{\circ} \mathrm{N}$. Progress in Oceanography, 130, 91-111.

https://doi.org/10.1016/j.pocean.2014.10.006

Mercier, H., Lherminier, P., Sarafanov, A., Gaillard, F., Daniault, N., Desbruyères, D., et al. (2015). Variability of the meridional overturning circulation at the Greenland-Portugal OVIDE section from 1993 to 2010. Progress in 
Oceanography, 132, 250-261. https://doi.org/10.1016/j.pocean.2013.11.001

Østerhus, S., Woodgate, R., Valdimarsson, H., Turrell, B., de Steur, L., Quadfasel, D., et al. (2019). Arctic Mediterranean exchanges: a consistent volume budget and trends in transports from two decades of observations. Ocean Science, 15(2), 379-399. https://doi.org/10.5194/os-15-379-2019

Pollard, R. T., Read, J. F., Holliday, N. P., \& Leach, H. (2004). Water masses and circulation pathways through the Iceland basin during Vivaldi 1996. Journal of Geophysical Research C: Oceans, 109(4), 1-10.

https://doi.org/10.1029/2003JC002067

Pujol, M.-I. I., Faugère, Y., Taburet, G., Dupuy, S., Pelloquin, C., Ablain, M., \& Picot, N. (2016). DUACS DT2014: the new multi-mission altimeter data set reprocessed over 20 years. Ocean Science, 12(5), 1067-1090. https://doi.org/10.5194/os-12-1067-2016

Rayner, D., Hirschi, J. J. M., Kanzow, T., Johns, W. E., Wright, P. G., FrajkaWilliams, E., et al. (2011). Monitoring the Atlantic meridional overturning circulation. Deep Sea Research Part II: Topical Studies in Oceanography, 58(17-18), 1744-1753. https://doi.org/10.1016/j.dsr2.2010.10.056

Reverdin, G., Niiler, P. P., \& Valdimarsson, H. (2003). North Atlantic Ocean surface currents. Journal of Geophysical Research C: Oceans, 108(1), 2-1. https://doi.org/10.1029/2001jc001020

Rossby, T., \& Flagg, C. N. (2012). Direct measurement of volume flux in the FaroeShetland Channel and over the Iceland-Faroe Ridge. Geophysical Research Letters, 39(7), n/a-n/a. https://doi.org/10.1029/2012GL051269

Sarafanov, A., Falina, A., Mercier, H., Sokov, A., Lherminier, P., Gourcuff, C., et al. (2012). Mean full-depth summer circulation and transports at the northern periphery of the Atlantic Ocean in the 2000s. Journal of Geophysical Research: Oceans, 117(1), n/a-n/a. https://doi.org/10.1029/2011JC007572

Schmidtko, S., Johnson, G. C., \& Lyman, J. M. (2013). MIMOC: A global monthly isopycnal upper-ocean climatology with mixed layers. Journal of Geophysical Research: Oceans, 118(4), 1658-1672. https://doi.org/10.1002/jgrc.20122 Sherwin, T. J., Griffiths, C. R., Inall, M. E., \& Turrell, W. R. (2008). Quantifying the 
overflow across the Wyville Thomson Ridge into the Rockall Trough. Deep-Sea Research Part I: Oceanographic Research Papers, 55(4), 396-404.

https://doi.org/10.1016/j.dsr.2007.12.006

Souza, A. J., Simpson, J. H., Harikrishnan, M., \& Malarkey, J. (2001). Flow structure and seasonality in the Hebridean slope current. Oceanologica Acta, 24(SUPPL.), 63-76. https://doi.org/10.1016/s0399-1784(00)01103-8

Thurnherr, A.M., (2014). How to Process LADCP Data with the LDEO Software (versions IX.7 IX.10),

https://www.bodc.ac.uk/data/documents/nodb/pdf/ladcp_Ideo_processing_IX.7_I X.10.pdf

Volkov, D. L. (2005). Interannual Variability of the Altimetry-Derived Eddy Field and Surface Circulation in the Extratropical North Atlantic Ocean in 1993-2001. Journal of Physical Oceanography, 35(4), 405-426. https://doi.org/10.1175/JPO2683.1

Zhao, J., Bower, A., Yang, J., \& Lin, X. (2018). Meridional heat transport variability induced by mesoscale processes in the subpolar North Atlantic. Nature Communications, 9(1), 1-9. https://doi.org/10.1038/s41467-018-03134-x 